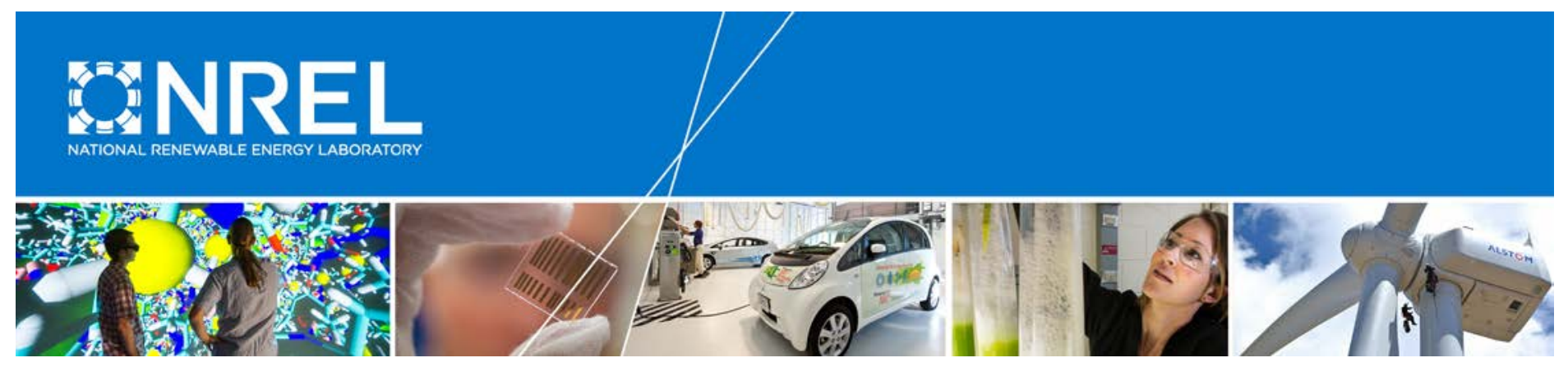

\title{
Competitive Electricity Market Regulation in the United States: A Primer
}

Francisco Flores-Espino, Tian Tian, Ilya Chernyakhovskiy, and Megan Mercer National Renewable Energy Laboratory

Mackay Miller

National Grid

NREL is a national laboratory of the U.S. Department of Energy Office of Energy Efficiency \& Renewable Energy Operated by the Alliance for Sustainable Energy, LLC

This report is available at no cost from the National Renewable Energy Laboratory (NREL) at www.nrel.gov/publications.

Technical Report

NREL/TP-6A20-67106

December 2016

Contract No. DE-AC36-08G028308 


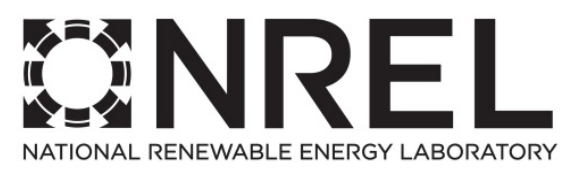

\section{Competitive Electricity Market Regulation in the United States: A Primer}

Francisco Flores-Espino, Tian Tian, Ilya Chernyakhovskiy, and Megan Mercer National Renewable Energy Laboratory

Mackay Miller

National Grid

Prepared under Task No. IGIN.1810
NREL is a national laboratory of the U.S. Department of Energy Office of Energy Efficiency \& Renewable Energy Operated by the Alliance for Sustainable Energy, LLC

This report is available at no cost from the National Renewable Energy Laboratory (NREL) at www.nrel.gov/publications.

\section{Technical Report}

NREL/TP-6A20-67106

December 2016

Contract No. DE-AC36-08G028308
National Renewable Energy Laboratory 15013 Denver West Parkway

Golden, CO 80401

303-275-3000 • www.nrel.gov 


\section{NOTICE}

This report was prepared as an account of work sponsored by an agency of the United States government. Neither the United States government nor any agency thereof, nor any of their employees, makes any warranty, express or implied, or assumes any legal liability or responsibility for the accuracy, completeness, or usefulness of any information, apparatus, product, or process disclosed, or represents that its use would not infringe privately owned rights. Reference herein to any specific commercial product, process, or service by trade name, trademark, manufacturer, or otherwise does not necessarily constitute or imply its endorsement, recommendation, or favoring by the United States government or any agency thereof. The views and opinions of authors expressed herein do not necessarily state or reflect those of the United States government or any agency thereof.

This report is available at no cost from the National Renewable Energy Laboratory (NREL) at www.nrel.gov/publications.

Available electronically at SciTech Connect http:/www.osti.gov/scitech

Available for a processing fee to U.S. Department of Energy and its contractors, in paper, from:

U.S. Department of Energy

Office of Scientific and Technical Information

P.O. Box 62

Oak Ridge, TN 37831-0062

OSTI http://www.osti.gov

Phone: 865.576.8401

Fax: 865.576.5728

Email: reports@osti.gov

Available for sale to the public, in paper, from:

U.S. Department of Commerce

National Technical Information Service

5301 Shawnee Road

Alexandria, VA 22312

NTIS http://www.ntis.gov

Phone: 800.553 .6847 or 703.605 .6000

Fax: 703.605.6900

Email: orders@ntis.gov 


\section{Acknowledgments}

This report was funded under the U.S.-China Renewable Energy Partnership through the U.S. Department of Energy (DOE) Office of Energy Efficiency and Renewable Energy's (EERE's) International Team. The authors would like to thank the U.S.-China Renewable Energy Partnership team for the opportunity to collaborate on the scoping and development of this study. The authors also wish to thank DOE for the sponsorship and guidance on this work, particularly Arlene Fetizanan from EERE. For their review and comments, the authors would like to thank Kevin Porter from Exeter Associates; Yongqiang Zhao and Linlin Qi from the Energy Research Institute of the National Development and Reform Commission; and Joyce McLaren, Michael Milligan, Paul Schwabe, Jeffrey Logan, and Karin Haas from the National Renewable Energy Laboratory. Any errors or omissions are solely the responsibility of the authors. 


$\begin{array}{ll}\text { Abbreviations and } & \text { Acronyms } \\ \text { AC } & \text { alternating current } \\ \text { APPA } & \text { American Public Power Association } \\ \text { BA } & \text { balancing authority } \\ \text { DC } & \text { direct current } \\ \text { CAISO } & \text { California Independent System Operator } \\ \text { DR } & \text { demand response } \\ \text { ED } & \text { economic dispatch } \\ \text { EIA } & \text { U.S. Energy Information Administration } \\ \text { EIM } & \text { energy imbalance market } \\ \text { EPA } & \text { U.S. Environmental Protection Agency } \\ \text { ERCOT } & \text { Electric Reliability Council of Texas } \\ \text { FERC } & \text { Federal Energy Regulatory Commission } \\ \text { FTR } & \text { financial transmission rights } \\ \text { GIZ } & \text { (Deutsche) Gesellschaft für Internationale Zusammenarbeit } \\ \text { IOU } & \text { investor-owned utility } \\ \text { IPP } & \text { independent power producer } \\ \text { ISO } & \text { independent system operator } \\ \text { ISO-NE } & \text { ISO New England } \\ \text { LMP } & \text { locational marginal price } \\ \text { LSE } & \text { load-serving entity } \\ \text { MISO } & \text { Midcontinent Independent System Operator } \\ \text { NERC } & \text { North American Electric Reliability Corporation } \\ \text { PJM } & \text { PJM Interconnection, formerly Pennsylvania New Jersey } \\ & \text { Maryland Interconnection LLC } \\ \text { PSCo } & \text { Public Service Company of Colorado } \\ \text { PUC } & \text { public utility commission } \\ \text { PURPA } & \text { Public Utilities Regulatory Policies Act } \\ \text { RAP } & \text { Regulatory Assistance Project } \\ \text { RTO } & \text { regional transmission organization } \\ \text { UC } & \text { unit commitment } \\ \text { VG } & \text { variable (renewable energy) generation } \\ & \end{array}$




\section{Table of Contents}

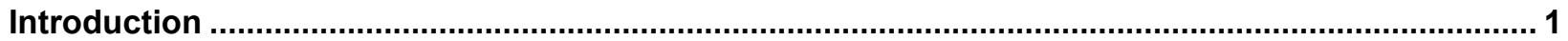

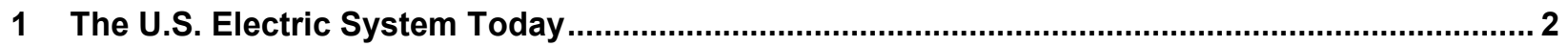

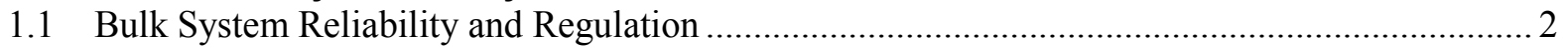

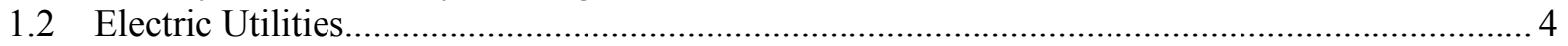

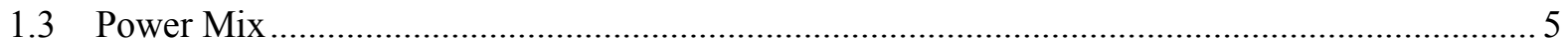

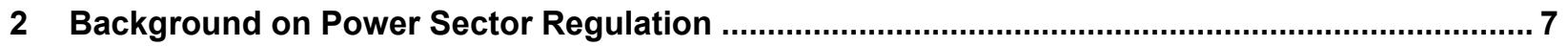

2.1 Electric Utilities as Natural Monopolies ................................................................................. 7

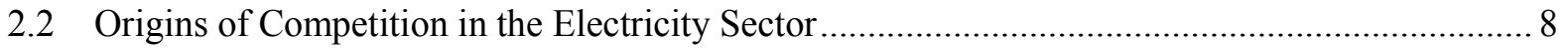

2.2.1 States' Role in Forming Competitive Markets............................................................ 9

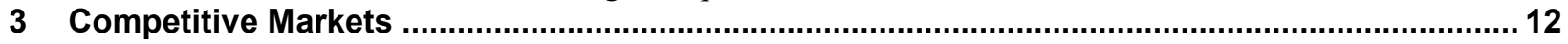

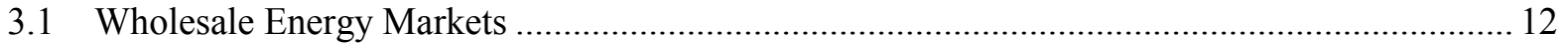

3.1.1 Unit Commitment and Economic Dispatch............................................................ 12

3.1.2 Locational Marginal Pricing and Power Delivery Schedules........................................ 13

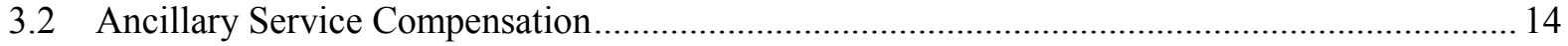

3.2.1 Market-Based Services: Regulating and Contingency Reserves................................... 14

3.2.2 Cost-Based Services: Voltage Support and Black Start Capability .............................. 15

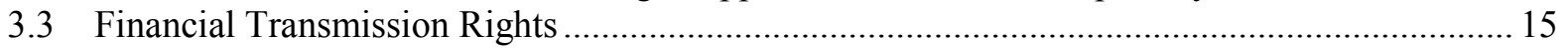

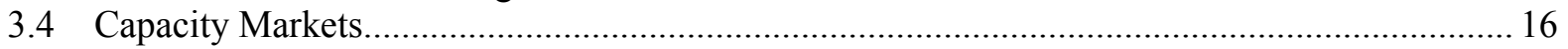

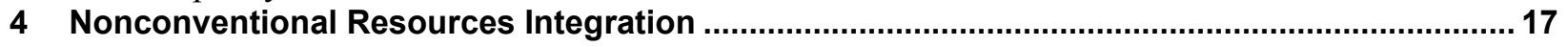

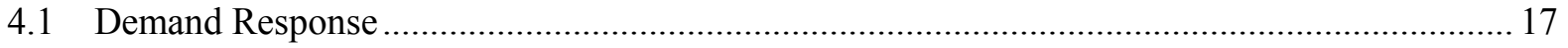

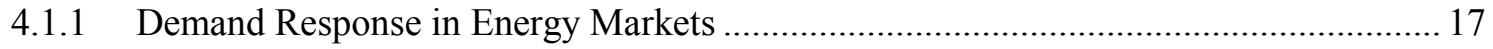

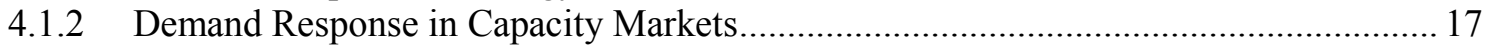

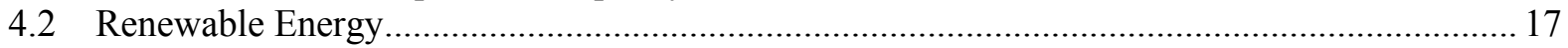

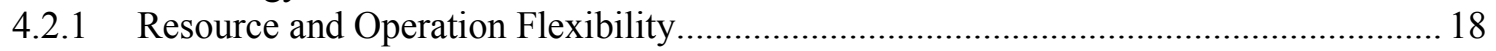

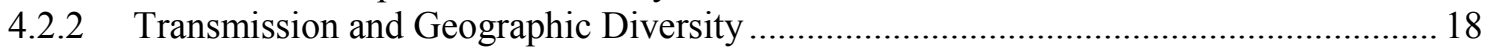

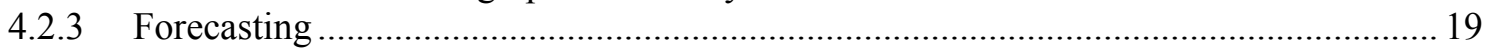

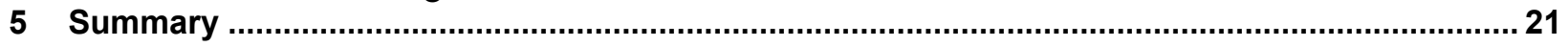

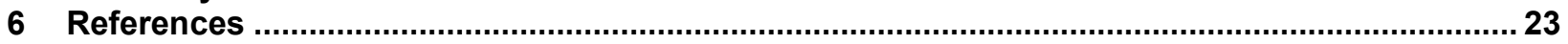

Appendix A. Midcontinent Independent System Operator ......................................................... 30

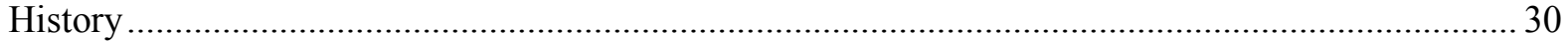

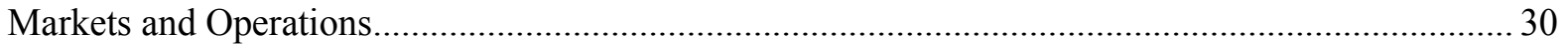

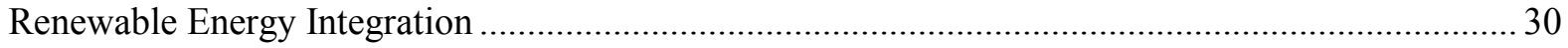

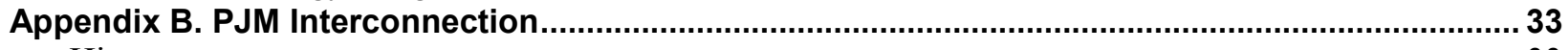

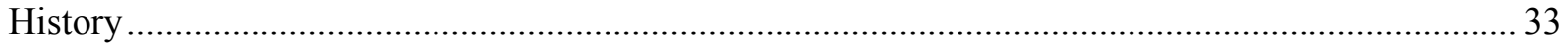

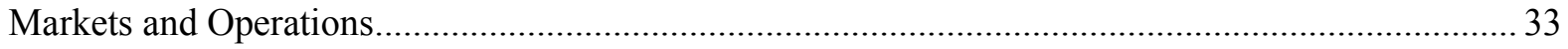

Renewable Energy Integration ................................................................................................... 33

Appendix C. Public Service Company of Colorado (PSCo) Balancing Authority .......................... 36

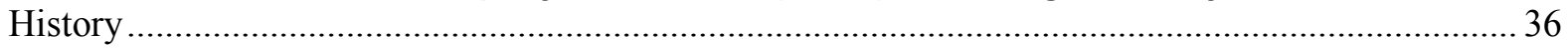

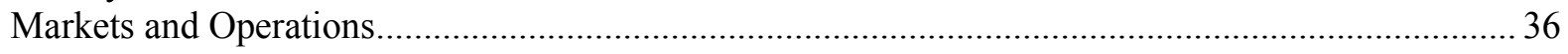

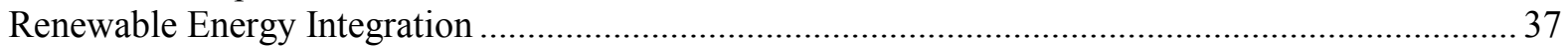




\section{List of Figures}

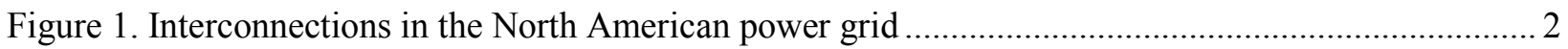

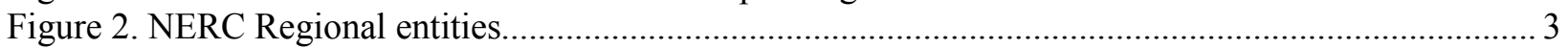

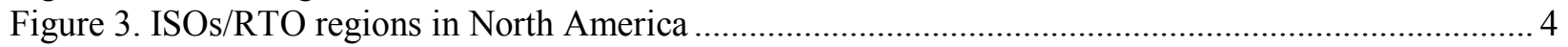

Figure 4. Share of total number of utilities and retail sales by category .................................................. 5

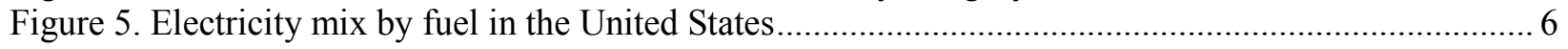

Figure 6. Timeline of annual capacity additions in the United States by fuel and important events............ 7

Figure 7 . Total capacity additions between 1970 and 1979 by fuel type .............................................. 9

Figure 8. Nominal and real wellhead natural gas prices, U.S. average 1982-1996.............................. 10

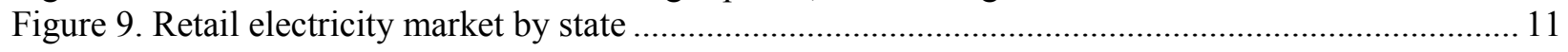

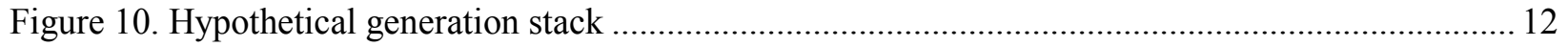

Figure 11. ERCOT's contour map showing LMPs at different nodes in ERCOT on May 11, 2015......... 13

Figure 12. Illustration of reserve types ...................................................................................... 15

Figure 13. Aggregation of solar PV plants in Southern California..................................................... 19

Figure 14. Effects of forecast lead time and dispatch schedule on reserve requirements......................... 20

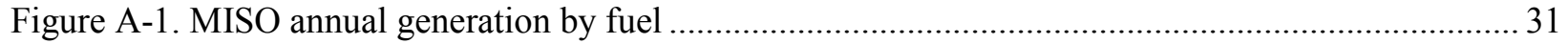

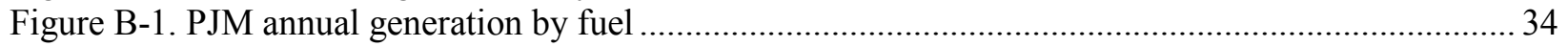

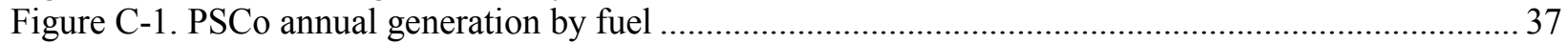




\section{Introduction}

The electricity system in the United States has evolved constantly for more than a century. The system began as a patchwork of small, independent systems and is now a highly complex, interconnected system serving 150 million customers. The system consists of approximately 200,000 miles of high-voltage lines and has an average reliability between $99.9 \%$ and $99.99 \%$ (APPA 2015; Gellings, Samotyj, and Howe 2004; EEI 2016).

In many countries, current regulations reflect a vertical model, which was replaced in much of the United States during the wave of electricity sector restructuring of the 1990s and early 2000s that introduced competitive markets. The purpose of this report is to describe the regulations that the federal government and the states have implemented to safeguard the quality, reliability, and economic efficiency of the power supply in the restructured markets of the United States. The emphasis of the report is on wholesale electricity markets, including enabling regulation and the motivations that lead to wholesale electricity market implementation. The information in this report could help inform regulators and stakeholders in international markets looking at restructuring their electricity sectors.

The first section of the report reviews the entities and infrastructure that comprise the U.S. electric system today. The second section describes the vertical integration regulatory paradigm in the electric utility industry and the motivations that lead regulators to introduce competition (as they are documented). The third section shows the basic underpinnings of electricity markets in the United States and describes the different products traded in those markets. The fourth and final section describes resources that have relatively short histories - demand response (DR) and variable energy resources - and their integration in existing wholesale markets. Finally, the Appendices contain three stand-alone fact sheets that illustrate how Midcontinent Independent System Operator (MISO), PJM, and Public Service Company of Colorado (a vertically integrated utility) have implemented some of the concepts presented in this report. 


\section{The U.S. Electric System Today}

The electric system that serves the United States is divided into three interconnections, which also cover parts of Canada and Mexico. The interconnections servicing the contiguous United States are the Western Interconnection, the Eastern Interconnection and the Electric Reliability Council of Texas (ERCOT) Interconnection (Figure 1). While all the power generation plants within each interconnection are synchronized and electrically interconnected, the three interconnections are not synchronized, and alternating current (AC) power must be converted to direct current (DC) power to be transferred between interconnections. Therefore, there is little electricity flow or system coordination between the interconnections, and electricity markets do not cross the boundaries. The operating frequency for all interconnections in North America is $60 \operatorname{Hertz}(\mathrm{Hz})$.

\section{North American Electric Reliability Corporation Interconnections}

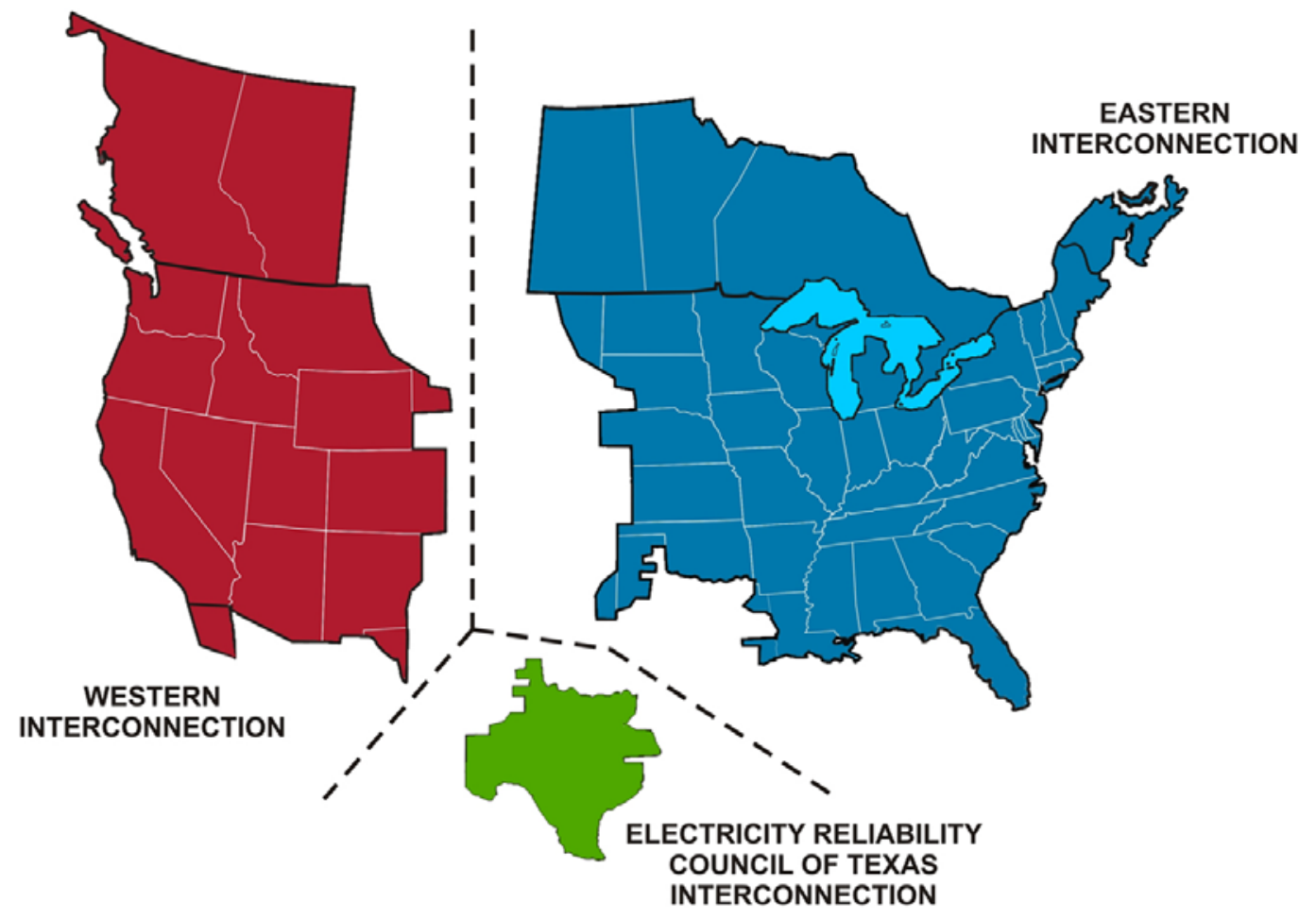

Figure 1. Interconnections in the North American power grid

Source: NERC (2016a)

\subsection{Bulk System Reliability and Regulation}

The North American Electric Reliability Corporation (NERC) is a nonprofit organization working to ensure the reliability of the North American bulk power system. NERC develops and enforces reliability standards, assesses the system's reliability, and trains the electric system professionals. Eight regional entities (Figure 2) under NERC monitor and enforce compliance with NERC's reliability standards within their respective territories. All bulk power system 
owners, operators, and users in the United States are required by law to comply with NERC's reliability standards (NERC 2016a).

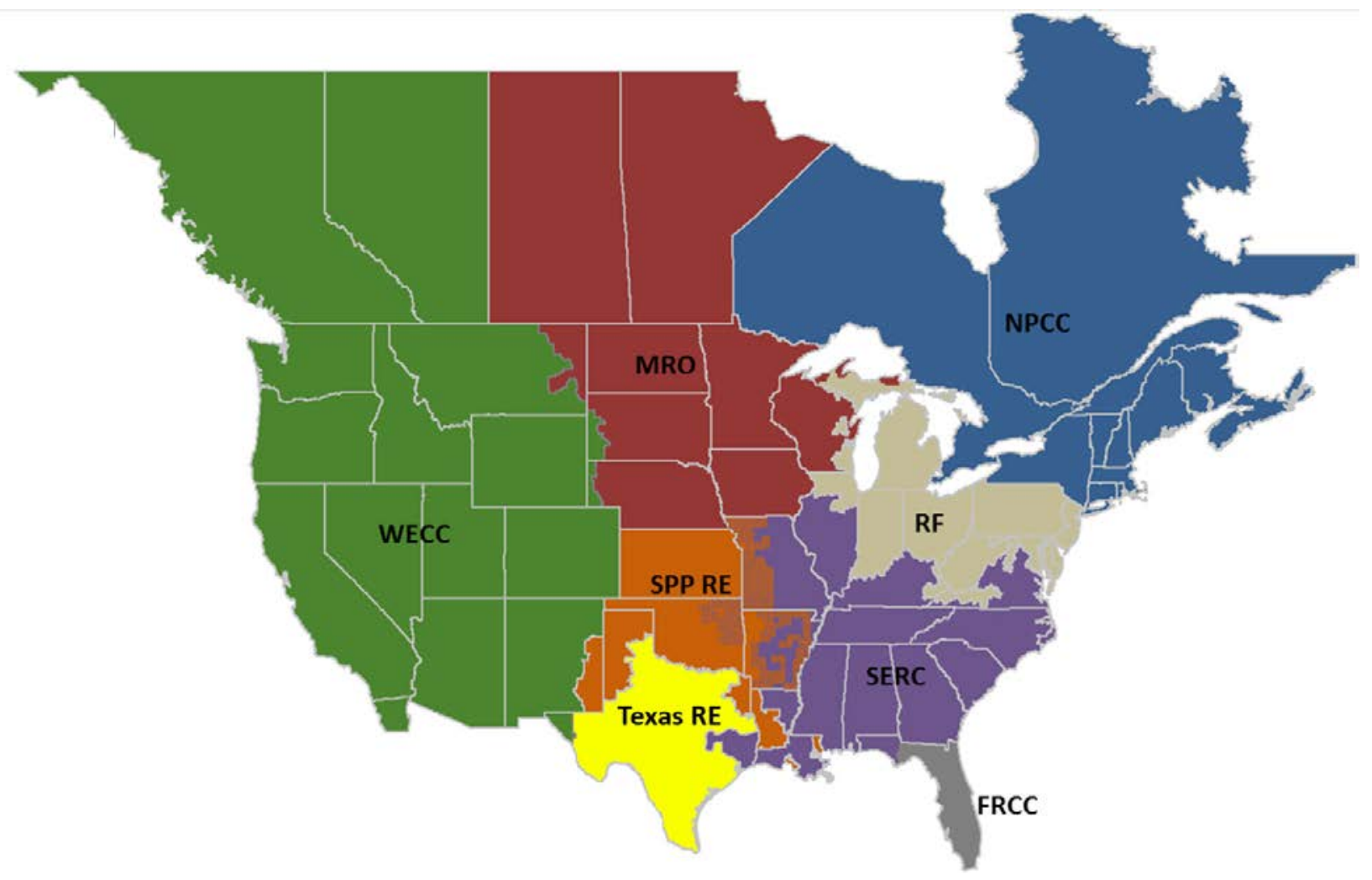

Figure 2. NERC Regional entities

Source: NERC (2016a)

Electricity supply and demand within each interconnection are balanced within smaller geographical areas called control areas, or balancing authorities (BAs). BAs are responsible for balancing generation to load on real-time, according to standards developed by NERC and the Federal Energy Regulatory Commission (FERC) (McLellan and Opatrny 2011). BAs work under the oversight of 12 wide-area Reliability Coordinators (NERC 2016b). 107 unique BAs operate in NERC's territory as of August 2014 (NERC 2014). In some areas, balancing is the responsibility of an independent system operator (ISO), which operates the system and markets under rules specified by state regulatory authorities under FERC.

FERC is an independent federal agency that regulates the interstate transmission and wholesale sale of electricity. FERC reviews and approves interstate transmission reliability standards developed by NERC. FERC also monitors wholesale energy markets to ensure their competitiveness, fairness, and efficiency and to detect market manipulation and rule violations. FERC's additional activities include reviewing corporate activities of public utilities (e.g., mergers, acquisitions, and issuances of securities) and licensing hydropower projects (FERC 2016a).

Independent system operators and regional transmission organizations (ISOs/RTOs) are organizations established to provide non-discriminatory access to the electric grid. Their 
essential functions include power system planning, regional electric grid operation and monitoring, and wholesale market administration (ISO-NE 2016a). FERC requires that ISOs/RTOs operate and make decisions independently of market participants. As illustrated by Figure 3, seven ISOs/RTOs are operating in the United States as of May 2016. See Section 2 for more information about ISOs/RTOs.

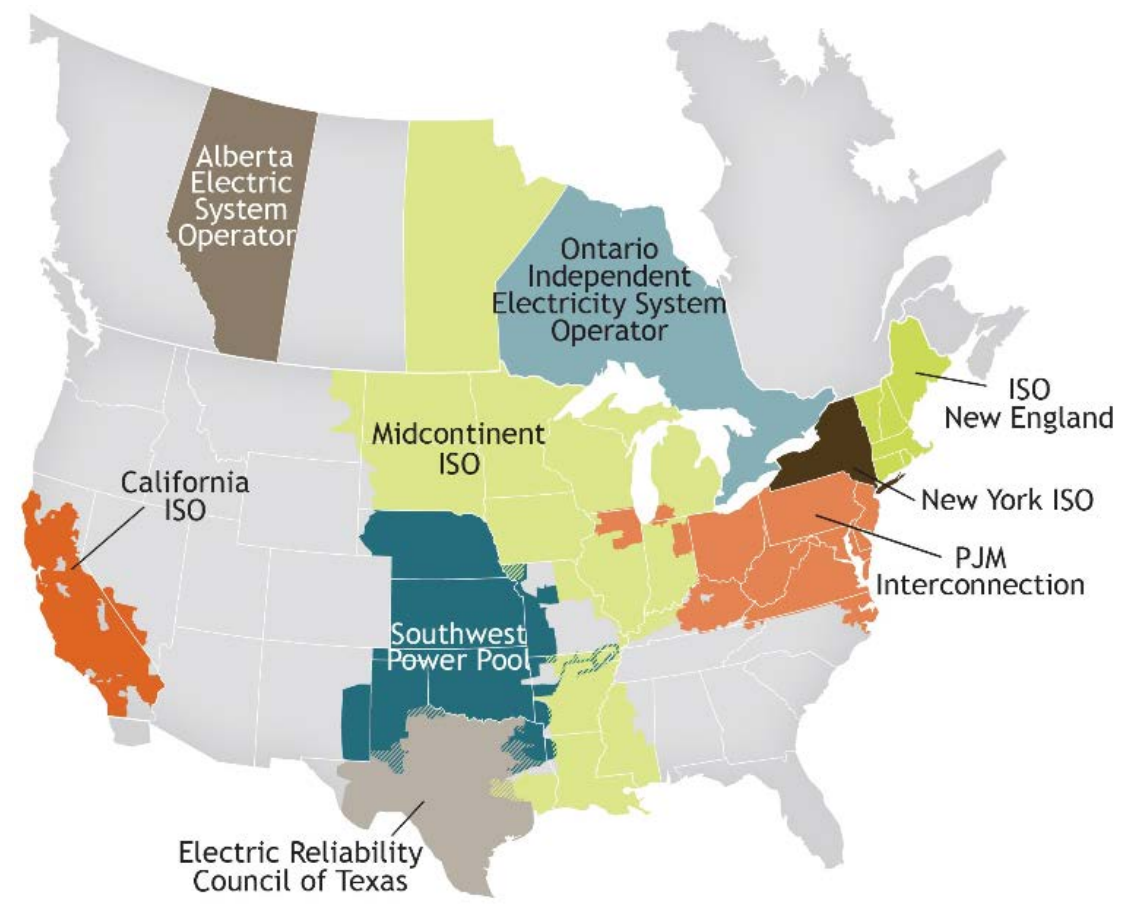

Note: Regions outside of the nine ISO/RTO areas, consisting of balancing authorities and utilities, do not fall under the jurisdiction of ISOs/RTOs.

Figure 3. ISOs/RTO regions in North America

Source: ISORTO.org

\subsection{Electric Utilities}

U.S. electric utilities can be grouped into five categories based on ownership structure. Publicly owned utilities, also known as municipal utilities, are owned by the local community and operated by local governments (e.g., cities and towns). These utilities own the generation, transmission, and distribution in their service territories. Electric cooperatives, which typically operate in rural areas, are owned and controlled by their members. Distribution cooperatives can buy power from generation and transmission cooperatives or procure from other utilities or from the market. Investor-owned utilities (IOUs) are private companies owned by investors holding their stock. Four federal power agencies, known as Power Marketing Administrations, ${ }^{1}$ operate electric systems within their territories. They sell electricity generated by federally owned facilities, which are primarily hydroelectric, at the wholesale level. Federal power agencies generally do not own generation assets ${ }^{2}$ and do not distribute power to customers (EIA 2013a).

\footnotetext{
${ }^{1}$ The four Power Marketing Administrations are: the Bonneville Power Administration, the Western Area Power Administration, the Southeastern Power Administration, and the Southwestern Power Administration.

${ }^{2}$ Generation assets operated by federal power agencies mostly belong to federal agencies (e.g., Army Corps of Engineers, Bureau of Reclamation, Bureau of Indian Affairs, and International Boundary and Water Commission).
} 
In competitive markets, power marketers buy electricity and sell it for a profit. These entities typically do not own generation or transmission assets (EIA 2016). Power marketers and IOUs operate for a profit, whereas cooperatives, public utilities, and federal power agencies are nonprofit entities.

State public utility commissions (PUCs) regulate retail sales, prices, and service of electricity. PUCs oversee public utilities to ensure they provide a safe and reliable service at just and reasonable rates for consumers. PUCs typically regulate IOUs and most PUCs have limited authority over publicly owned utilities and cooperatives (EPA 2010). Local governments or elected utility boards govern municipal utilities and electric cooperatives in most states (RAP 2011).

In 2013, the United States had 3,292 operating utilities. ${ }^{3}$ Publicly owned utilities represented $60.9 \%$ of the total number of utilities in the United States, cooperatives $26.5 \%$, power marketers $6.4 \%$, IOUs $5.8 \%$, and federal power agencies $0.3 \%$. In terms of electricity retail sales in megawatt-hours (MWh), IOUs accounted for $53.3 \%$ of total sales, power marketers 19.1\%, publicly owned utilities $15.4 \%$, cooperatives $10.9 \%$, and federal agencies $1.2 \%$ (APPA 2014), as shown in Figure 4.

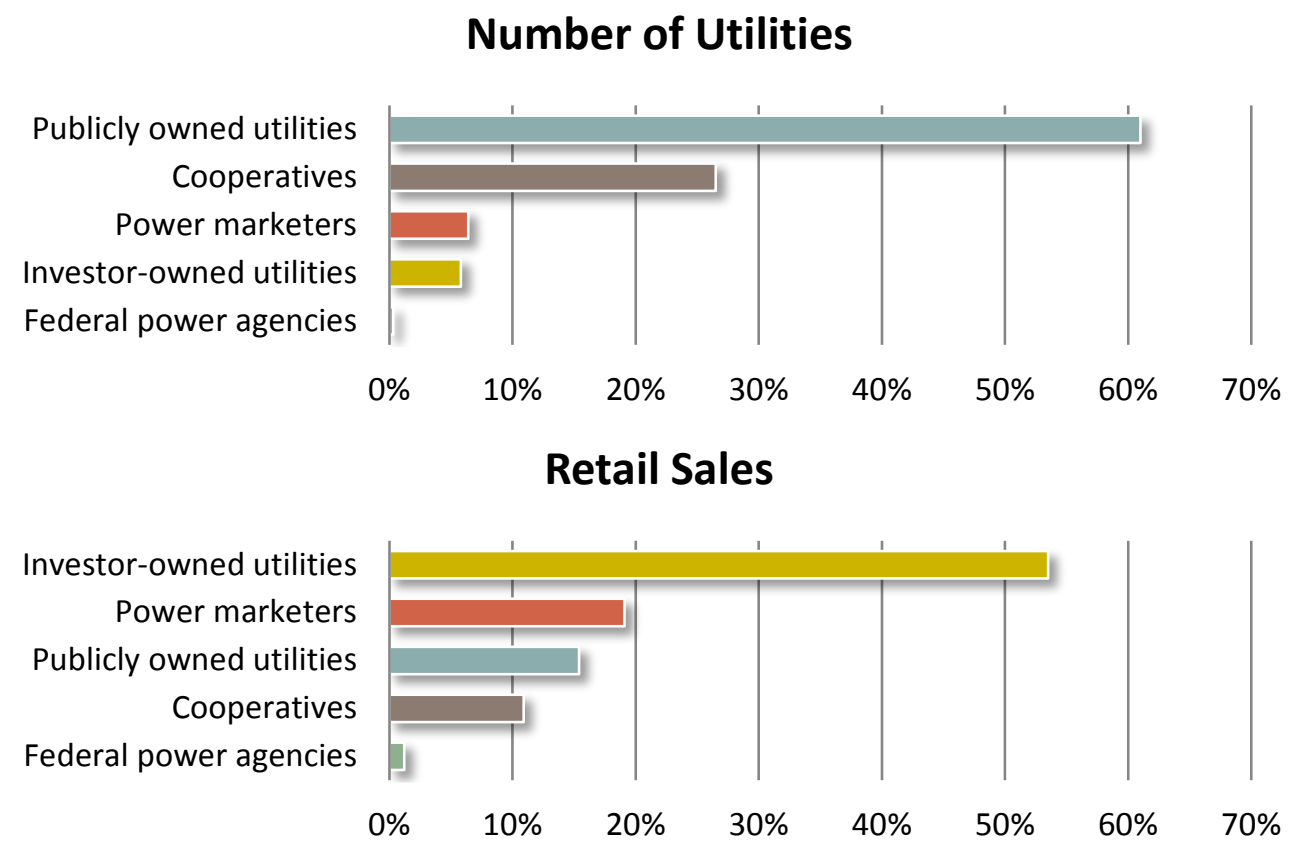

Figure 4. Share of total number of utilities and retail sales by category

Data source: APPA (2014)

\subsection{Power Mix}

Of the total electricity generated in 2015 in the United States, coal-fired generation represented $33 \%$, natural gas 33\%, and nuclear 19\%. Renewable energy accounted for $13 \%$ of total generation, with hydroelectric plants producing roughly one-half of that percentage. Wind power

${ }^{3}$ Utilities operating in more than one jurisdiction are counted once per subsidiary. 
represented the majority of non-hydro renewable generation in 2015 with $5 \%$ of total generation, biomass $1.6 \%$, geothermal $0.4 \%$, and utility-scale solar $0.6 \%$ (EIA 2016).

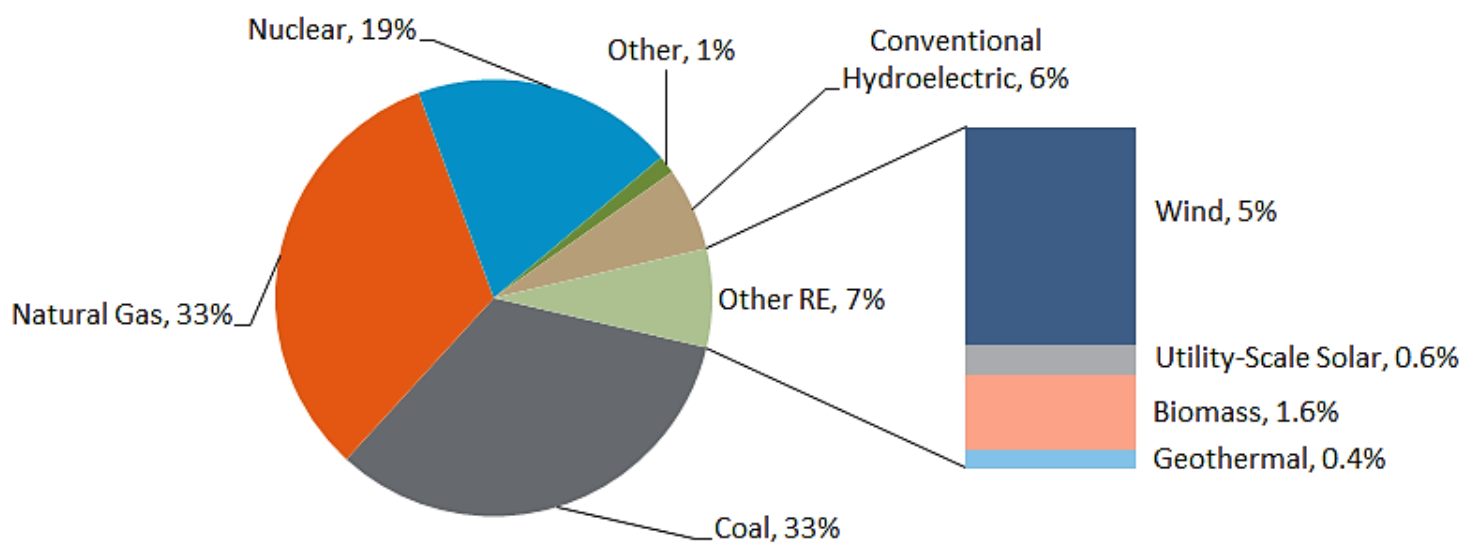

Figure 5. Electricity mix by fuel in the United States

Data source: EIA (2016) 


\section{Background on Power Sector Regulation}

In the United States, the generation, transmission, distribution, and sale of electricity are regulated by government entities at the local, state, and federal levels. FERC generally regulates interstate transmission and wholesale power sales at the federal level, ${ }^{4}$ while states regulate retail sales and the operation of distribution networks. Depending on state law, local governments may regulate siting and other zoning and land use issues for transmission and generation facilities. In most cases, the state has preemptive authority over local governments (RAP 2011; EEI 2013).

Figure 6 presents a timeline of important events in the power sector from 1950 to 2014, including FERC orders and federal legislation. In addition, it displays capacity additions by fuel type and year to illustrate the evolution of the power mix in the United States during this period. The rest of this section describes each policy and event in detail.

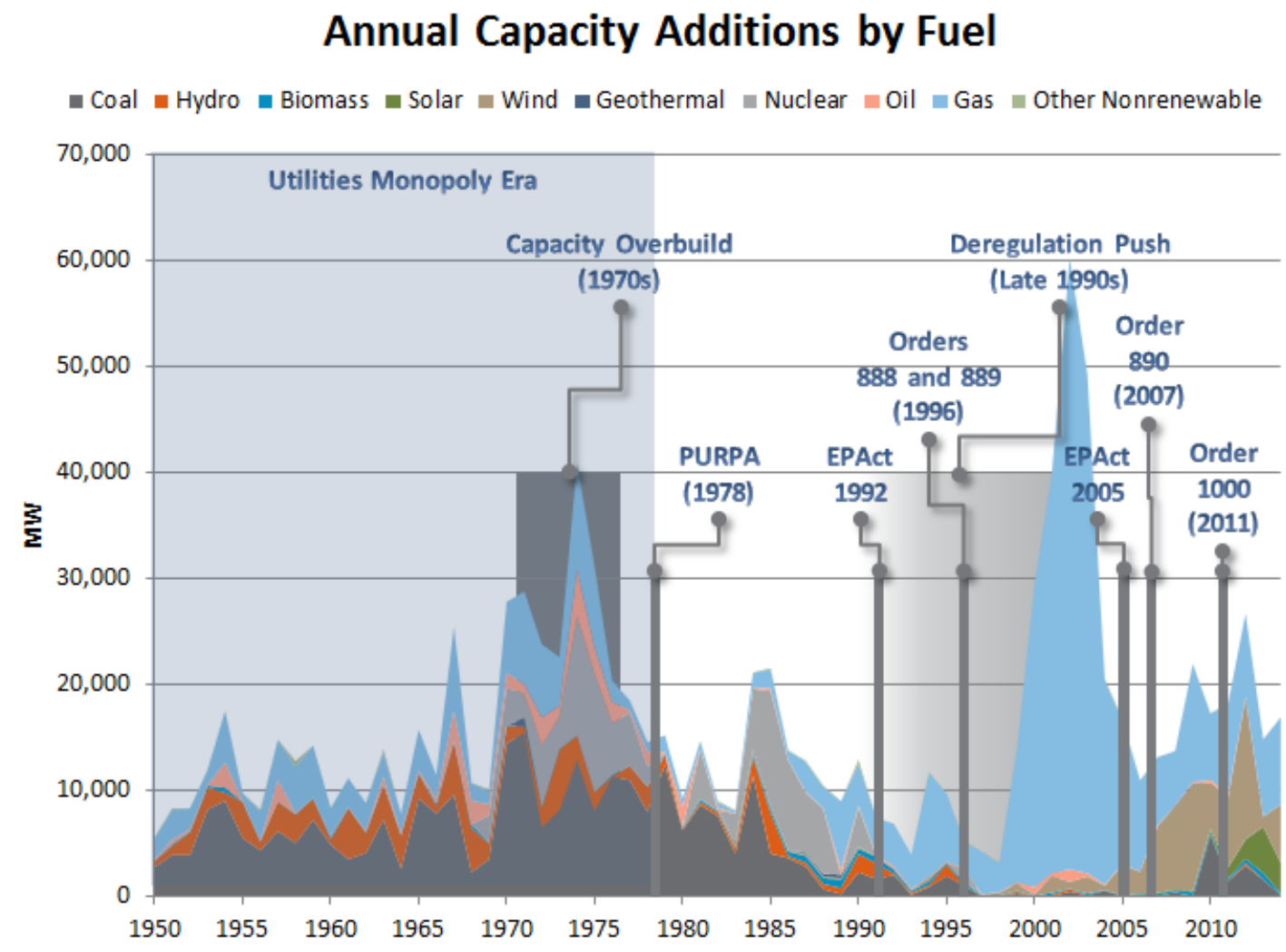

Figure 6. Timeline of annual capacity additions in the United States by fuel and important events Data source: SNL (2016)

PURPA = Public Utilities Regulatory Policies Act EPAct $=$ Energy Policy Act

\subsection{Electric Utilities as Natural Monopolies}

Competition in certain economic activities, such as supply of water and electricity, may translate into higher costs due to the duplication of infrastructure. In such cases, a natural monopoly may service the market more efficiently (Ran Kim and Horn 1999). Power generation, transmission,

\footnotetext{
${ }^{4}$ ERCOT regulates its own wholesale market because the entire interconnection lies within Texas.
} 
and distribution have large fixed costs and low marginal costs; having two or more electricity providers in the same service area could multiply the cost. Thus, electric utilities were operated and regulated at the state level as natural monopolies throughout the United States for most of the $20^{\text {th }}$ century. Markets in which utilities are treated as natural monopolies can be referred to as traditionally regulated markets.

In traditionally regulated markets, a single electric utility serves all the customers within a designated area, referred to as its service territory. Utilities in these markets are typically vertically integrated. Vertically integrated utilities manage all — and may own most — of the segments of the electricity value chain within their service territory, including generation, transmission, and distribution assets (Posner 2015). State governments regulate these vertically integrated utilities to balance their monopolistic market power with the public interest. State regulators review utilities' reliability, safety, and environmental standards, evaluate utilities' plans to meet future demand, and ensure that customers have access to service under reasonable rates (RAP 2011; Warwick 2002).

\subsection{Origins of Competition in the Electricity Sector}

In 1978, Congress enacted the Public Utilities Regulatory Policies Act (PURPA), requiring utilities to purchase power from small power plants, including renewable energy and cogeneration, at avoided cost rates. PURPA opened the monopolistic electricity market to independent power producers (IPPs) and spurred contracts between IPPs and vertically integrated utilities in states such as California, Texas, New York, and Massachusetts (Joskow 1997; Elefant 2011; FERC 2012).

After the enactment of PURPA, a few states set up competitive bidding mechanisms to meet additional energy needs and to select the most economic generation (Kahn et al. 1989). The Energy Policy Act, first passed in 1992, gave FERC authority to grant transmission access on request. The combination of PURPA, competitive bidding mechanisms, and the Energy Policy Act of 1992 expanded the market for IPPs (Joskow 1997).

In 1996, FERC issued Orders 888 and 889, which required utilities to publish separate rates for electrical services (i.e., unbundling wholesale generation, transmission, and ancillary services) and instructed owners of transmission systems to offer power producers open, nondiscriminatory access to their transmission system (Lamoureux 2001). Thus, Order 888 suggested the formation of ISOs - that is, independent organizations that have operational control and offer open transmission access.

In 1999, FERC found that there were still significant barriers to ensuring that the United States had an abundant and supply of electricity at the "lowest price possible for reliable service." 5 This prompted FERC to initiate a rulemaking process to address (1) the perceived lack of equitable access to transmission infrastructure, and (2) economic and engineering inefficiencies in the operation of the grid (Merrill 2000). The process culminated in the issuance of Order 2000, which established the concept of the regional transmission organization (RTO) and outlined its functions and characteristics. Additionally, the order encouraged transmission owners to participate in RTOs. ISOs and RTOs have similar responsibilities, which include facilitating

${ }^{5}$ FERC Docket No. RM99-2-000; Order No. 2000 
nondiscriminatory access to transmission infrastructure and coordinating, controlling and monitoring the use of the transmission grid in their respective territories (see Section 1.1).

Through Order 2000, FERC encouraged the formation of RTOs across most of the country; however, some utilities and state regulators chose not to join RTOs in order to maintain control over system operations (Warwick 2002). ISOs and RTOs currently serve about two-thirds of electricity consumers in the United States, with traditional BAs serving the remainder (NYISO 2016).

FERC Order 890 was issued in 2007 to require openness, transparency, coordination, and impartiality in transmission planning processes. FERC Order 1000, issued in 2011 with the goal of increasing collaboration in the planning and construction of regional and inter-regional transmission, encourages equitable and economical cost allocations for new transmission lines (PJM 2016b; Enerdynamics 2012).

\subsubsection{States' Role in Forming Competitive Markets}

In the early 1990s, some states started to restructure their electric markets in support of federal efforts to promote competition in the electricity generation segment. Several states impelled utilities within their jurisdiction to divest their generation assets through legislative mandates or by conditioning regulatory approvals (Kwoka, Pollitt, and Sergici 2010). As a result, 20\% of all generation capacity in the United States was sold or transferred ownership between 1998 and 2001 (Bushnell and Wolfram 2005).

A number of factors motivated some states to consider electricity market restructuring. In the 1970 s, the high cost of imported fuels caused customer rates to increase. Utilities responded by building power plants that used domestic, lower-cost fuels (Figure 7). Exacerbated by sagging demand during this period, overbuilding of capacity and the concomitant capital costs triggered further rate increases (Warwick 2002).

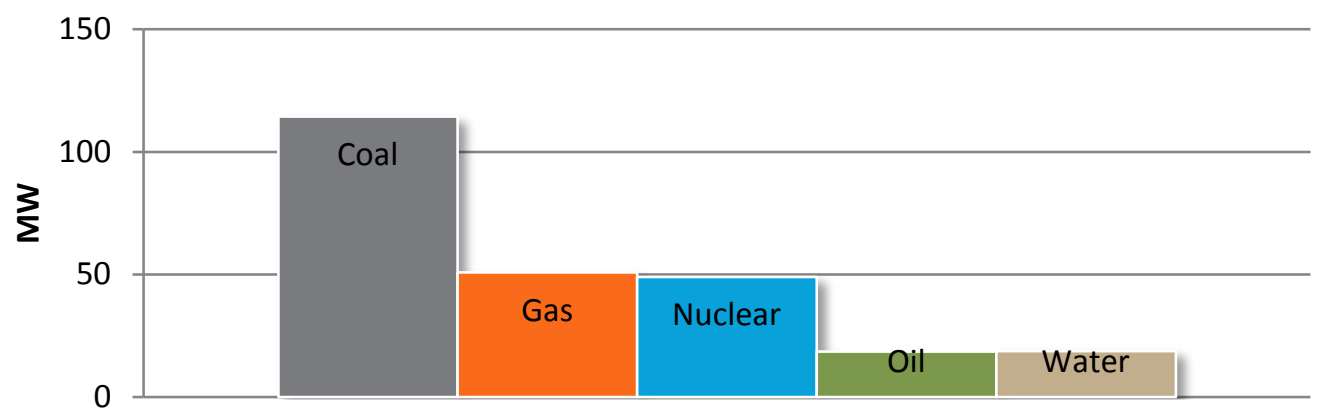

Figure 7. Total capacity additions between 1970 and 1979 by fuel type

Source: SNL (2016)

Some large industrial customers and other ratepayers perceived utility mismanagement and lax regulatory oversight as the main causes for rate increases. One motivation for the transition to a competitive electricity sector was to shift the costs of capacity overbuilding, construction cost overruns, and other contributing factors of rate hikes from consumers to suppliers (MossavarRahmani 2003). Moreover, because the rates of return for utilities, as set by regulators, are proportional to investments added to the rate base, utilities could be incentivized to overinvest in 
infrastructure, particularly when the rate of return is set high (Boonin 2008). Prevention of utility overinvestment served as another motivation for implementing competitive models (RAP 2011).

Deregulation of the natural gas industry also increased the impetus for electricity deregulation. The decline in real wholesale and retail natural gas prices in the late 1980s and early 1990s was attributed to the deregulation and introduction of competition in the natural gas industry (Figure 8) (Jess 1997; Juris 1998). In the mid-1990s, states began to look at competition as a way of increasing the electric power industry's efficiency and lowering electricity rates. By April 2001, 24 states had passed legislation related to electricity market restructuring (Wolfram 2003).

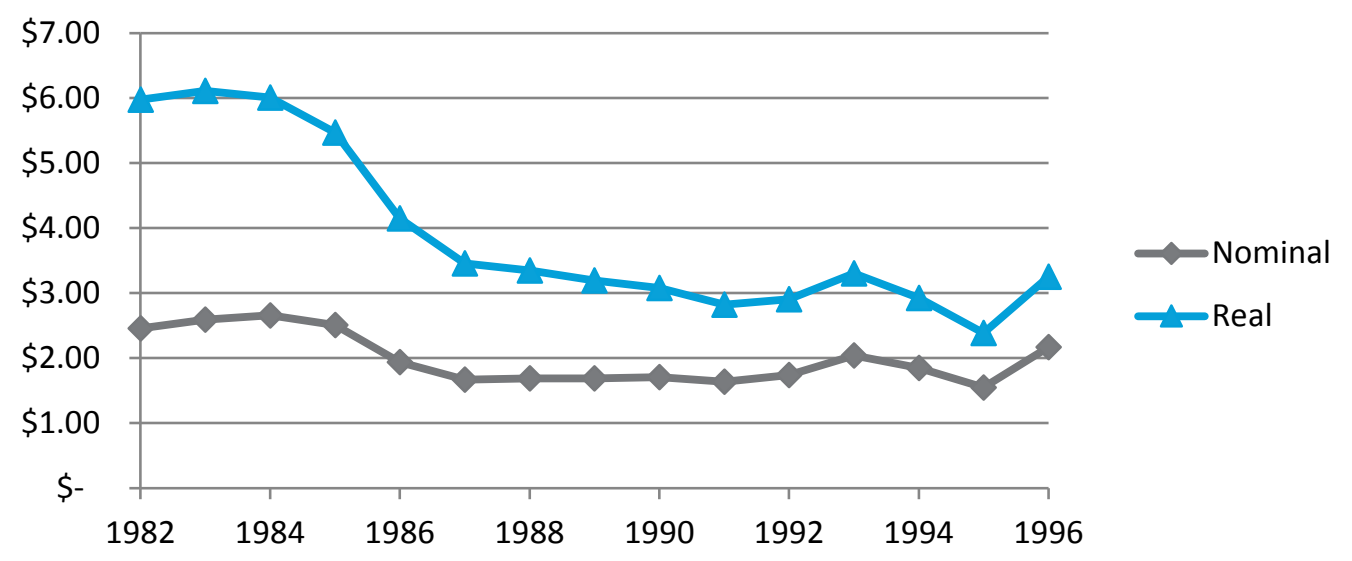

Figure 8. Nominal and real wellhead natural gas prices, U.S. average 1982-1996 Source: EIA (2015)

Between the summers of 2000 and 2001, just a few years after enacting its deregulation law, California experienced a severe electricity crisis that sent wholesale prices from an average of $\$ 30$ per MWh to over $\$ 150$ per MWh (Cicchetti, Dubin, and Long 2004). In 2003, the Northeast region of the United States (and parts of Canada) experienced a blackout that affected 50 million customers. The perception that both incidents were linked to deregulation dampened the deregulation movement across the country and caused some states to suspend their efforts (Griffin and Puller 2005; Johnson 2006).

As of July 2015, 14 states have broad-based customer access to competitive retail markets (Figure 9). Access to competitive retail markets in Arizona, California, Michigan, Montana, and Oregon is mostly limited to commercial and industrial customers (O'Connor and O'ConnellDiaz 2015). 


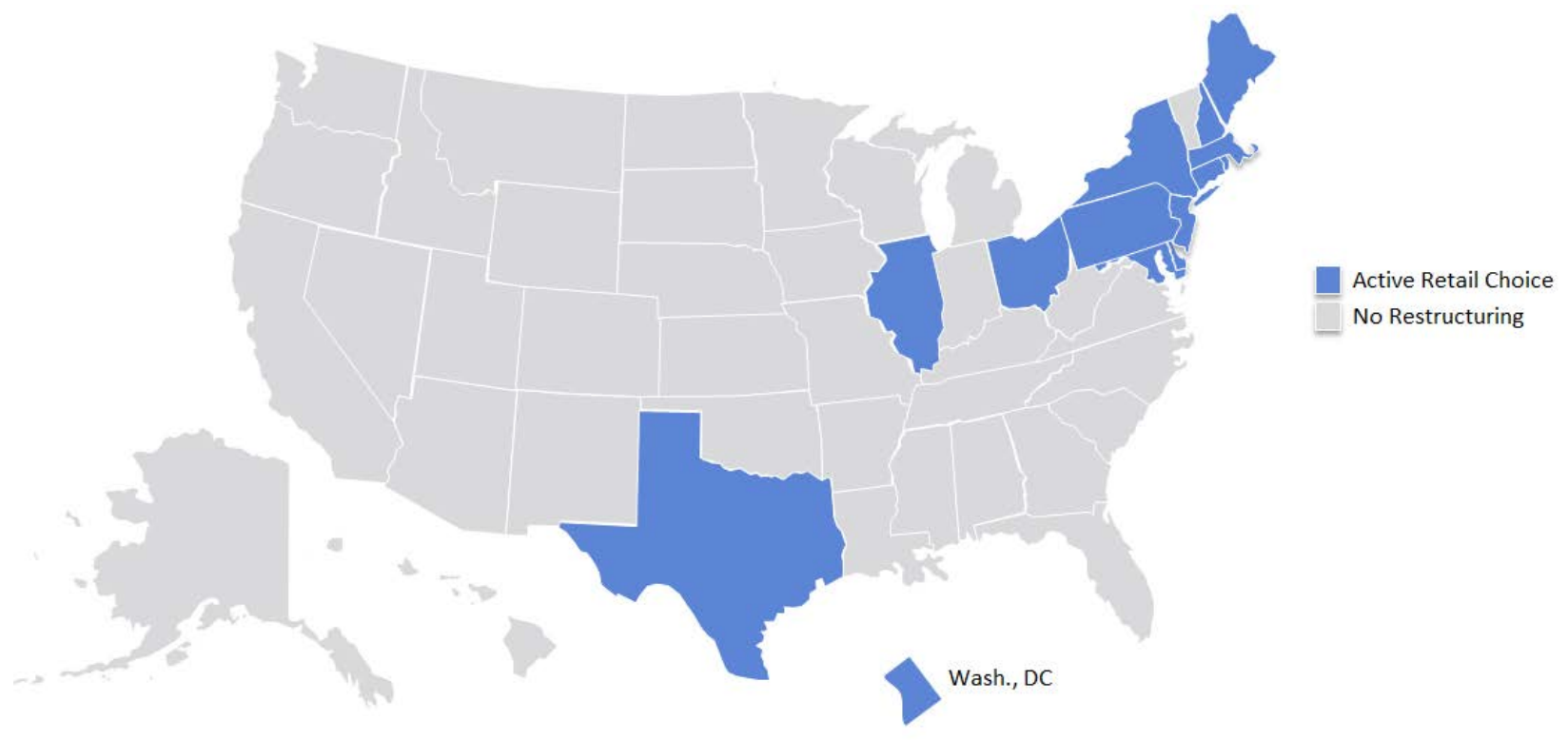

Figure 9. Retail electricity market by state

Source: O'Connor and O'Connell-Diaz (2015) 


\section{Competitive Markets}

\subsection{Wholesale Energy Markets}

A transparent wholesale spot market $^{6}$ coordinated by an independent entity forms the foundation of competitive electricity markets in the United States. The goal of wholesale electricity markets is to produce a least-cost economic dispatch of generation resources that meets demand and ensures system reliability. Energy prices are determined by the balance between supply and demand based on bids and offers submitted by market participants (Hogan 1998).

\subsubsection{Unit Commitment and Economic Dispatch}

In competitive markets, generators submit offers to the system operator based on the incremental cost to produce energy and the amount of power they want to sell. Arranging all the supply offers in ascending order of marginal cost renders a supply curve, also known as generation stack or dispatch curve (Figure 10). In a hypothetical scenario, lower-cost units would be dispatched first and dispatched generators would be paid at a rate that reflects the cost to serve the next increment of load (i.e., the marginal price). In reality, several factors, such as transmission constraints and each generator's characteristics, lead to deviations from marginal cost-based dispatch curves (Posner 2015; EIA 2012; Lelic 2016a).

Figure 10 shows a hypothetical generation stack. In this case, a demand of $36 \mathrm{GW}$ produces a marginal cost of $\$ 65.65$ per $\mathrm{MWh}$. When the demand increases to $42 \mathrm{GW}$, the marginal price increases to $\$ 103.44$ per MWh.

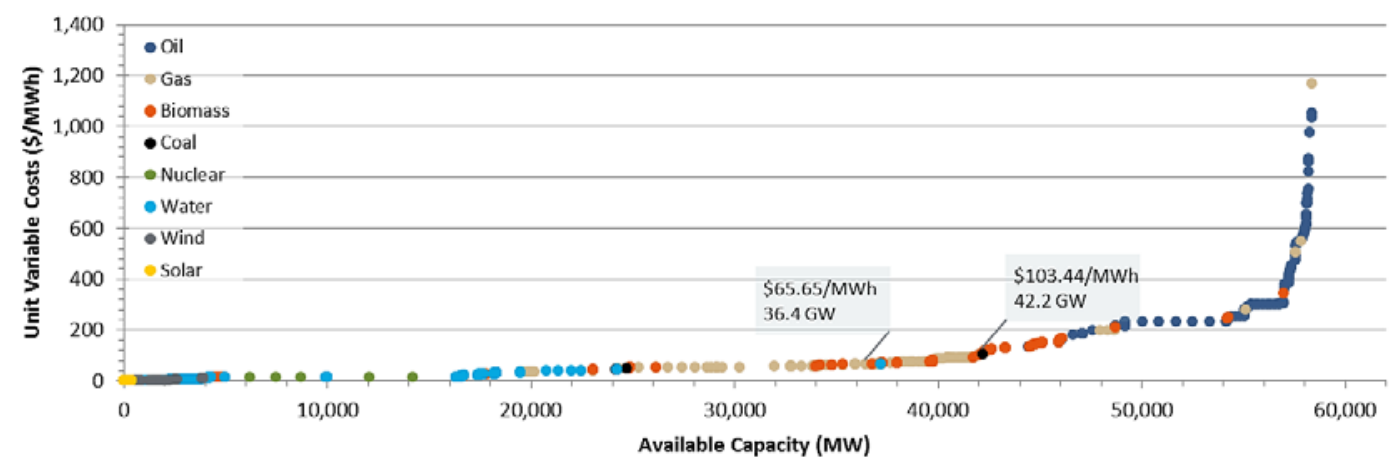

Figure 10. Hypothetical generation stack

Unit commitment is a process used by system operators to select generation units to meet demand reliably. Unit commitment takes into account each resource's characteristics, such as ramp rates, minimum run time, and minimum notification time. Large numbers of generators participate in each energy market in the United States. This means that balancing electricity demand and supply can be accomplished in more than one way at any given time. The objective of economic dispatch is to meet electricity demand at the lowest cost. Generally, operators use both unit commitment and economic dispatch to commit and dispatch generation to balance supply and demand (Lelic 2016b).

\footnotetext{
${ }^{6}$ In spot markets, the contracts under which commodities are sold are effective immediately and delivery is scheduled in the short-term.
} 


\subsubsection{Locational Marginal Pricing and Power Delivery Schedules}

ISOs/RTOs within the United States use locational marginal pricing (LMP) to price energy transactions at each network node. LMP includes the marginal cost of energy plus the cost of transmission congestion and losses. ISOs/RTOs use LMPs as a market-based mechanism to price the efficient use of transmission infrastructure in cases where congestion prevents the least-cost dispatch from reaching the nodes where power is needed (Ea Energy Analyses and Hagman Energy 2012). Security-constrained unit commitment and security-constrained economic dispatch are unit commitment and economic dispatch algorithms used to calculate LMPs while taking generation and transmission limitations into account (CAISO 2009; DOE 2007).

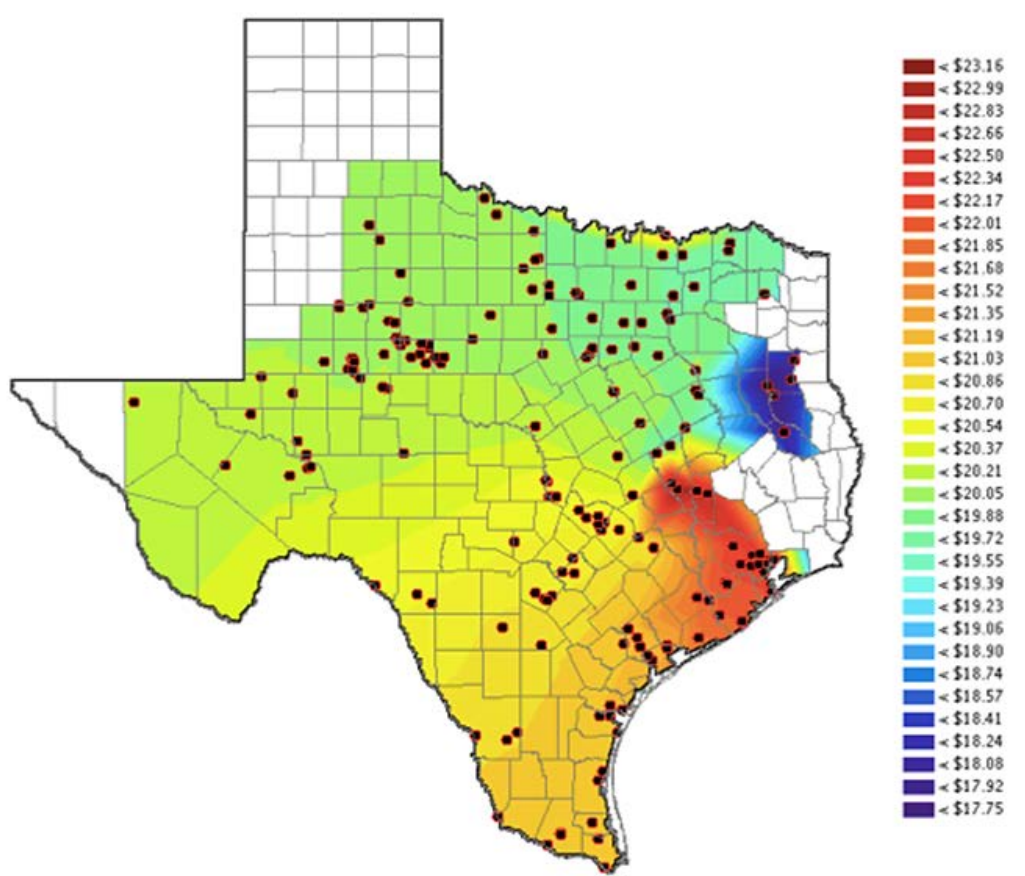

Figure 11. ERCOT's contour map showing LMPs at different nodes in ERCOT on May 11, 2015 Source: ERCOT (2016)

ISOs/RTOs in the United States run day-ahead and real-time markets. These two terms refer to the time at which the buy-and-sell transaction is made relative to the delivery of energy. Most of the energy volume is traded in day-ahead markets, where market participants submit bids and offers for electric energy delivered on the next day. In real-time markets, the volume of energy traded is the difference between energy commitments cleared in day-ahead markets and the energy actually needed in the system to meet demand. Real time prices are based on actual operating conditions and costs (Hausman et al. 2006). In real-time markets, LMPs are calculated in 5-minute intervals ${ }^{7}$ or more frequently if the network is experiencing extraordinary conditions (Price, n.d.). In day-ahead markets, the commitment and dispatch interval is typically one hour.

\footnotetext{
${ }^{7}$ Market operators set dispatch intervals. Most U.S. markets have adopted five-minute intervals (Cochran et al. 2013).
} 
Day-ahead markets and other longer-term procurement options help participants hedge against the volatility of real-time markets (Turner 2016; Hausman et al. 2006). Longer-term price certainty helps generation plant developers secure long-term financing (Hogan 1993).

\subsection{Ancillary Service Compensation}

Competitive markets have financial compensation mechanisms to encourage participants to offer non-energy products and services that contribute to the safe and efficient operation of the grid. Ancillary services are those services necessary to support the reliability of the transmission system, such as frequency regulation and black-start capabilities. The compensation for these services can be cost- or market-based. Prices paid to ancillary service suppliers reflect the marginal cost to provide services, which may include the cost of not selling energy in order to provide — or being available to provide — ancillary services (i.e., opportunity cost). Additional costs for ancillary service providers may come from less-efficient plant operation and increased equipment wear and tear maintenance (Kirby 2004).

\section{FERC Definition of Ancillary Services}

FERC defines ancillary services as: "those services necessary to support the transmission of electric power from seller to purchaser, given the obligations of control areas and transmitting utilities within those control areas, to maintain reliable operations of the interconnected transmission system. Ancillary services supplied with generation include load following, reactive power-voltage regulation, system protective services, loss compensation services, system control, load dispatch services, and energy imbalance services" (FERC 2016b.)

\subsubsection{Market-Based Services: Regulating and Contingency Reserves}

Regulating reserves are energy generation resources that can automatically change their output to compensate for short-term changes in load and keep the system frequency within preestablished parameters (as close to $60 \mathrm{~Hz}$ as technically possible in the case of the United States). Participants are paid to make their dispatchable generation available to ramp up or down as needed. Load-following resources work in a similar way, but at much slower ramp rates and higher output capacity swings. Both regulating and load following resources are used during the normal operation of the grid (Kirby 2007).

Contingency reserves are able to provide backup generation during unexpected events such as extreme weather and higher-than-average generator outages. Their response time is less than 10 minutes after notification. Spinning contingency reserves are capable of almost immediate response, but they consume fuel on standby mode. Supplemental contingency reserves offer a slower response of 30 to 60 minutes (Kirby 2007), but they do not consume fuel when they are not contributing electricity to the system. Replacement reserves, used to restore contingency reserves to their pre-contingency status, have a response time of up to 30 minutes after notification (Kirby 2004). Ramping reserve is the available capacity used to support active power balance during infrequent events of longer duration, such as during load or net load ramping events or errors in variable generation (VG) and load forecasting. Ramping reserve is a relatively new service currently under consideration by the California Independent System 
Operator (CAISO) and MISO (Ela et al. 2014; CAISO 2016; MISO 2016). Insufficient ramping capabilities may lead to the need for higher-cost peaking power generating units, which can cause electricity prices to increase (Ela et al. 2011).

Regulating and contingency reserves may be procured in day-ahead and real-time ancillary service markets administered by the system operator.

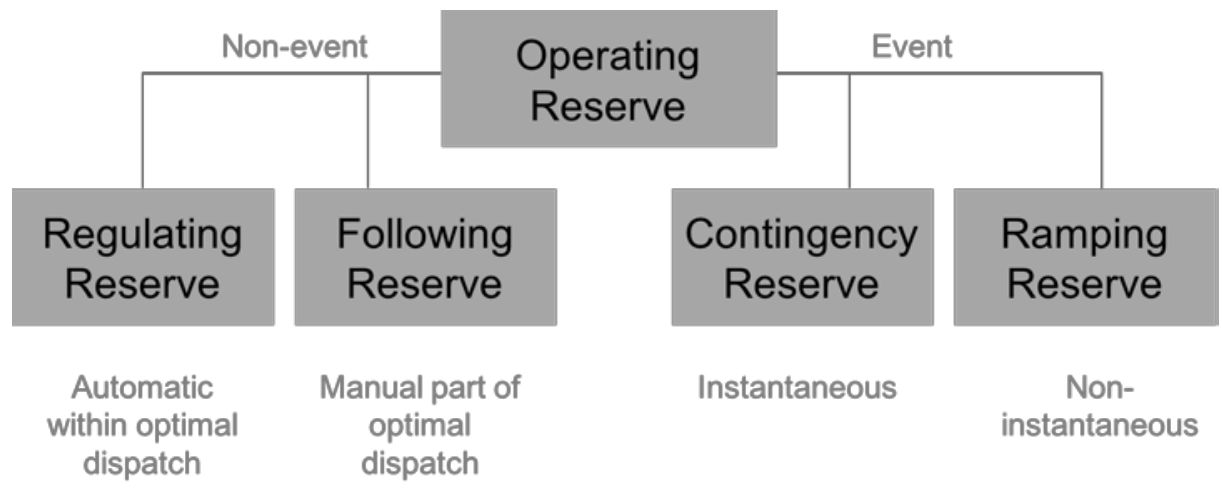

Figure 12. Illustration of reserve types

Adapted from Ela et al. (2011)

\subsubsection{Cost-Based Services: Voltage Support and Black Start Capability}

Cost-based services do not participate in bid-based markets. Typically, the need for these services depends on location.

Voltage support services entail the injection or absorption of reactive power from the grid to maintain transmission voltages and power factors within established limits. Service providers are paid according to a tariff calculated by the system operator. Transmission customers pay for voltage support through a tariff proportional to their monthly peak usage. Providers of voltage support services include generators and transmission owners. Under certain conditions, generators may need to curtail their real power output to provide reactive power, in which case they would receive compensation for lost revenues (Craan 2009).

Black start is the capability of certain types of generation units to start operation without the need of an alternative source of electric power. This type of unit is needed to restore power in the event of a complete system shutdown. Black start capability is a cost-based service. Providers submit their revenue requirements to the system operator based on operation and maintenance costs.

\subsection{Financial Transmission Rights}

As discussed in Section 3.1.2, LMPs include the cost of transmission congestion. The actual cost of congestion is uncertain and is unknown until the day-ahead market clears. Financial transmission rights (FTR $)^{8}$ allow the holder to pay ahead for transmission congestion costs, guaranteeing the price paid for the transmission congestion component of LMPs. FTRs can result in revenue if clearing prices are higher than the FTR, or FTRs can result in a charge when

\footnotetext{
${ }^{8}$ FTRs have different names depending on ISO/RTO, including Congestion Revenue Rights (CAISO and ERCOT), Transmission Congestion Contracts (NYISO) and FTR (ISO-NE, PJM, and MISO).
} 
clearing prices are lower. FTRs can help holders hedge against congestion costs. Market participants can also use FTRs to profit through arbitrage (ISO-NE 2016b).

\subsection{Capacity Markets}

Capacity markets have been established in different ISOs/RTOs in the United States since the 1990s. They aim to ensure network reliability by assisting in maintaining pre-established levels of planning reserve margins. Capacity markets are generally structured to provide a minimum level of revenue for a specified period of time (e.g., three years) for generators, which reduces operating and investment risks (Spees et al. 2013).

Revenue insufficiency, due to price volatility, caps on market prices, and other regulatory limits to market operations, could spur early power plant closures and discourage investments in new generation capacity (European Commission 2012). As a result, capacity may not keep pace with demand growth and the reliability of the grid could be compromised. Capacity payments aim to supplement generators' energy and ancillary services revenue streams and provide investors with more predictability (Caplan and McCullar 2013). Capacity payments are cleared in public auctions where load-serving entities (LSEs) seek to contract generation capacity-in addition to the capacity LSEs own or have contracted - in order to reach adequacy requirements. ISOs/RTOs coordinate and oversee capacity auctions and enforce a prescribed set of rules to determine capacity prices (Griffith 2008; FERC 2012).

Data from a study by Pfeifenberger and Spees (2013), covering more than ten years of capacity market experience in the United States, show that the capacity markets can guarantee a preset level of resource adequacy if the capacity payment is set appropriately. A few characteristics of successful capacity markets include well-defined resource adequacy goals, clear understanding of why an energy-only market is not achieving its resource adequacy goals, capacity products designed to address specific energy-only market shortcomings, and participation from all resource types, including DR (Pfeifenberger and Spees 2013).

Not all energy-only markets experience revenue inadequacy and capacity markets are not the only way to ensure network reliability in the face of revenue adequacy (Spees et al. 2013). In the United States, ERCOT does not have a capacity market. Alternatives to capacity markets include strategic reserves that are only used in case of resource inadequacy, operating reserve demand curves, emergency-only DR resources, high or no maximum price caps, and other mechanisms for administrative emergency intervention (Spees, et al. 2013; European Commission 2012). 


\section{Nonconventional Resources Integration}

With the rapid growth of renewable, energy efficiency, distributed generation, and other nonconventional energy resources, market mechanisms (e.g., DR) and tools (e.g., renewable energy forecasting), have been implemented by various system operators in the United States.

\subsection{Demand Response}

DR uses tariffs or programs to encourage short-term changes in electricity use by end consumers. Incentive-based demand response programs pay participating customers to reduce their load during shortage events or when the cost of generating electricity is higher. Load reduction on the customer side can be achieved through automatic controls or through pricing mechanisms that vary according to the time of day, the season, or grid conditions (DOE 2006).

DR can provide economic benefits by displacing the most expensive resources in competitive markets; that is, resources in the far-right side of the generation stack (see Figure 10). In 2013, the potential peak reduction in ISOs/RTO areas from demand response program was $29 \mathrm{GW}$ (FERC 2014). DR can also provide reliability, ancillary, and energy services cost-effectively; provide emergency resources to avoid outages; and increase system reliability, flexibility and market efficiency (Hurley et al. 2013).

\subsubsection{Demand Response in Energy Markets}

Reducing load during times of high demand can avoid the need for the most expensive generation resources. Typically, DR providers submit offers to curtail load in day-ahead and real-time energy markets (PJM 2016a). The payment that providers receive can be the market clearing price or a fraction of it. In 2011, FERC issued Order 745, establishing guidelines for the participation of DR in energy markets and called for ISOs/RTOs to pay DR resources the full market price of energy (Hurley et al. 2013). Order 745 was challenged in court under the argument that DR is a retail transaction and therefore outside the jurisdiction of FERC. However, the Supreme Court recently upheld Order 745, reaffirming FERC's jurisdiction to regulate the demand side of wholesale markets (Dyson and Kelly 2016).

\subsubsection{Demand Response in Capacity Markets}

In capacity markets, DR is used to ensure resource adequacy. Currently, DR participation in certain markets represents a significant portion of available capacity. In PJM, for example, DR accounts for almost 10\% of total available system capacity (Paulos 2014). Experience shows that DR can deliver resource adequacy cost-effectively. Payments to PJM capacity market participants were $\$ 11.8$ billion lower than what they would have been if no DR resources had been offered into the auction, according PJM's independent monitor (Monitoring Analytics 2010).

\subsection{Renewable Energy}

Renewable energy has unique characteristics that challenge the traditional operation of the electric grid and electricity markets. The characteristics that differentiate VG from conventional sources of electricity include: 
- VG increases net load ${ }^{9}$ variability

- VG has near-zero variable operation costs

- VG has a limited capacity value relative to its rated capacity (Ela et al. 2014).

The variable nature of wind and solar generation requires a higher amount of flexibility to maintain safe levels of short-term grid reliability. Operating conventional resources on a more flexible schedule could increase their operation costs. At moderate to high levels of VG, wind and solar variability may also require more operating reserves, which could result in higher clearing prices in reserve markets.

VG's low variable operation costs enable them to bid at zero or negative prices, ${ }^{10}$ reducing the clearing price paid to all energy markets participants. Additionally, VG variability can increase LMP volatility. This can lead to revenue uncertainty and insufficiency for conventional resources. Given the limited capacity value of wind and solar, revenue insufficiency (or uncertainty) for conventional resources could negatively affect the long-term reliability of the system (Ela et al. 2014).

The operational and institutional changes described in this section can help cost-effectively mitigate the challenges of variable renewable energy integration.

\subsubsection{Resource and Operation Flexibility}

System flexibility allows for the integration of higher levels of renewable energy integration. Adding flexible sources of generation or cycling existing plants more frequently increases the flexibility of the system. Cycling conventional resources, such as fossil-fuel thermal plants, increases wear and tear and can decrease their efficiency, which in turn increase operational costs. However, the operational cost increase is not very significant and in one recent study represented $2 \%$ of the savings in fuel costs (Lew et al. 2013).

Other sources of system flexibility include fast, automated DR resources and storage systems with high ramping rates such as flywheels, compressed-air energy storage, and pumped hydro.

Hourly dispatch may constrain operators' ability to manage variability. In contrast, sub-hourly resource scheduling and dispatch allow system operators to use the flexibility of existing resources to manage variability. Systems that use five-minute scheduling intervals serve most of the load in the United States (DOE 2011).

\subsubsection{Transmission and Geographic Diversity}

Additional transmission infrastructure can enable VG integration from diverse geographical locations, interconnect renewable energy generators in remote locations, and deliver ancillary services needed to equalize supply and demand (NERC 2009).

Geographic diversity in the location of variable resources helps smooth the variability of wind and solar resources. Figure 13 shows the effect of aggregating the output of a large number of

\footnotetext{
${ }^{9}$ Net load is defined as total load minus variable generation.

${ }^{10}$ Negative prices are the result of VG's near-zero variable costs coupled with incentives such as the federal production tax credit.
} 
PV plants in Southern California. The blue line shows a pattern that matches day-ahead forecasts more closely (Lew and Brinkman 2013).

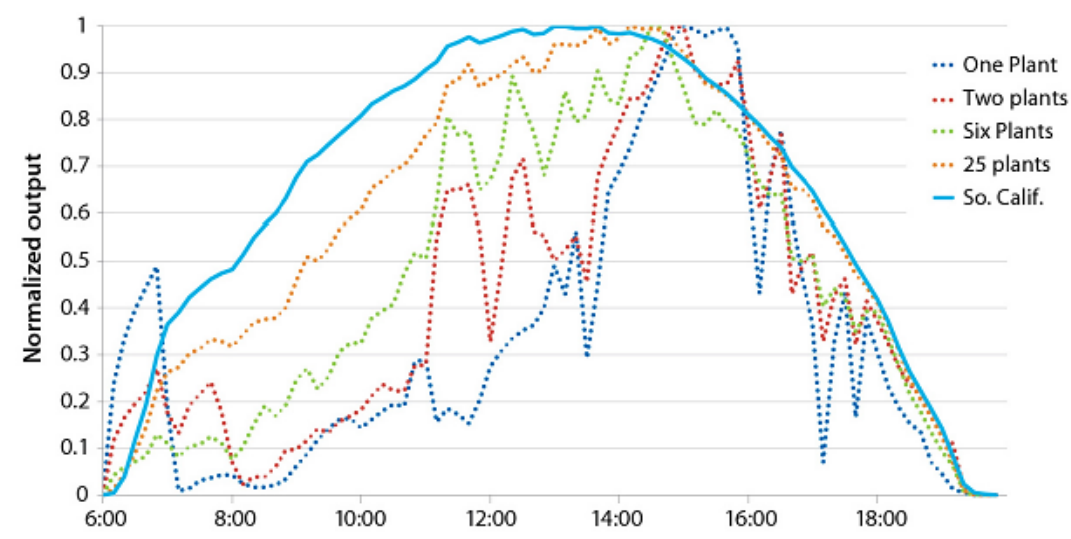

Figure 13. Aggregation of solar PV plants in Southern California

Source: Lew and Brinkman (2013)

Larger balancing areas increase the flexibility of the system because their larger geographic footprint includes a more diverse set of power generation sources (DOE 2011).

Different rules and designs for adjoining wholesale electricity markets can create inefficiencies at the interfaces, or seams, between two adjoining RTO/ISOs. Increasing coordination between neighboring markets helps address inefficiencies at the seams and can improve the economic value of capacity and energy transfers between markets (Garg 2015). For example, MISO coordinates with adjoining markets, such as PJM and the Southwest Power Pool, as well as other neighboring entities to put in place agreements and procedures to manage congestion at the seams. Multi-stakeholder working groups meet regularly to discuss joint operation agreements (MISO 2015).

Energy imbalance markets (EIMs) are voluntary real-time markets that aggregate the load and generation of several balancing areas or utility territories with the purpose of increasing system flexibility, geographic diversity and economic efficiency. CAISO and PacifiCorp, one of the largest utilities in the western United States, started an EIM in 2014 under CAISO's coordination. This EIM is designed to trade energy only in real-time; day-ahead trading and ancillary services are not included in the design (Hinman 2014). EIM participants waive normal transmission fees for power transfers. NV Energy in Nevada, Puget Sound Energy in Washington, and Arizona Public Service joined the EIM in 2016 (CAISO 2016b).

\subsubsection{Forecasting}

Wind and solar forecasting can help reduce the costs of integrating VG to the electric system. System operators can use VG forecasts to more efficiently commit or de-commit dispatchable generators to balance load and supply (Bird, Milligan, and Lew 2013). Shorter forecast horizons, combined with increased dispatch frequency, help operators reduce the amount of operating reserves at a given time (Figure 14). CAISO was the first operator to implement centralized wind forecasting in 2004. In a 2014 survey of system operators in the Western Interconnection, nearly all system operators reported using wind forecasts for day-ahead unit commitment (NREL 2015). 
Reserve Requirement Comparisons for Three Dispatch Schedule Options

Footprint EIM Case (Average, Max, and Min)

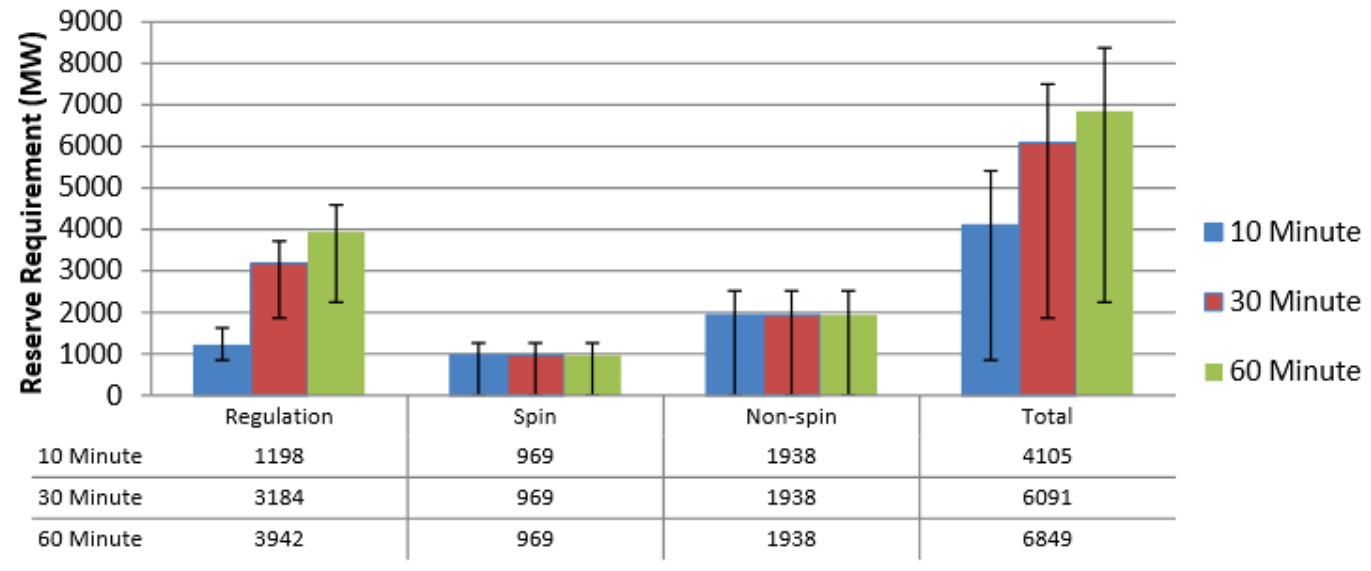

Figure 14. Effects of forecast lead time and dispatch schedule on reserve requirements

Source: King et al. (2011)

Advances in forecasting techniques, models, and computational capabilities have increased VG forecasting accuracy. Wind forecast errors range from $3 \%$ to $6 \%$ of rated capacity one hour ahead and $6 \%$ to $8 \%$ a day ahead. Compared to wind forecasting, solar forecasting is at an earlier developmental stage (NREL 2015). Forecast systems generally follow the same steps: prediction of wind or solar patterns based on weather forecasts and on-site observations, simulation of power generation, and regional power forecast (GIZ 2015). 


\section{Summary}

The electricity system in the United States is a complex mechanism where different technologies, jurisdictions, and regulatory designs interact. Today, two major models for electricity commercialization operate in the United States. One is the regulated monopoly model, in which state commissions regulate vertically integrated electricity providers. The other is the competitive model, in which power producers can openly access transmission infrastructure and participate in wholesale electricity markets. Regulators introduced competition in electricity markets with the goal of improving efficiency, lowering consumer cost, and reducing the barriers to participate as a producer. Competitive markets serve two-thirds of the customers in the United States. The goal of both models is to provide electricity safely and reliably to end consumers.

Independent entities with no financial stake on the outcome of electricity transactions operate wholesale markets. To participate in the market, power producers submit their bids for each scheduling period, which is typically five minutes long. Bids include asking price (based on the plant's marginal costs of operation) and capacity offered. In general, system operators dispatch the least cost resources first until demand is met. The most expensive resource sets the market's energy price. LMPs include three components - the market's energy price, congestion costs, and transmission losses.

Competitive markets are not limited to energy trading. Generation plants can provide other services to support the transmission of electricity. These services are known as ancillary services and include operating reserves, voltage support services, and black start. Some ancillary services are traded in wholesale markets. System operators also coordinate the trading of financial transmission rights, which allow the holder to pay ahead for transmission congestion costs and can be used as a form of hedging against cost volatility. Capacity payments have been introduced to increase network reliability by providing an additional source of revenue for power producers proportionally to their capacity factor.

The recent emergence of DR and renewable energy technologies has posed new challenges to competitive system administrators. DR mechanisms encourage consumers to change their use in the short term, mainly through tariffs and incentive programs. DR can displace the most expensive resources, increasing the economic efficiency of the system, and DR can provide reliability and ancillary services cost-effectively. FERC's Order 745 called for system operators to pay DR resources the full market price of energy. The Supreme Court recently upheld Order 745 .

Wind and solar generation increase net load variability and uncertainty which, holding other factors equal, can increase the cost and complexity of balancing the system's load. Measures that can cost-effectively mitigate the costs of integrating variable renewable energy into the system include resource and operation flexibility, adequate transmission infrastructure, geographic diversity, and forecasting.

Wind and solar have near-zero variable cost, which reduces the market clearing price proportionally to the amount of variable energy generation resources bidding on the market at a given time. This can create revenue uncertainty and deficiency for other current and prospective generators. In the long term, revenue uncertainty can decrease the reliability of the electricity 
system because existing participants may retire and prospective participants may choose not to participate. The goal of capacity markets is to increase revenue certainty for generators and, in turn, increase grid reliability.

The experience with competitive markets in the United States could offer lessons to markets in other regions of the world. The structure of the U.S. markets and their components are the results of a long evolution and the incorporation of lessons learned from market inefficiencies and failures. The Appendices - two for competitive markets, one for a regulated monopoly — can assist the reader in understanding the actual application of the concepts presented. 


\section{References}

APPA (American Public Power Association). 2014. 2015-16 Public Power Annual Directory \& Statistical Report. Arlington, VA: American Public Power Association. http://www.publicpower.org/files/PDFs/USElectricUtilityIndustryStatistics.pdf.

Bird, Lori, Michael Milligan, and Debra Lew. 2013. Integrating Variable Renewable Energy: Challenges and Solutions. NREL/TP-6A20-60451. Golden, CO: National Renewable Energy Laboratory. http://www.osti.gov/scitech/biblio/1097911.

Boonin, David M. 2008. “Allowed Return on Equity - Focus on Effective Regulation.” Presented at the NARUC Annual Convention, New Orleans, Louisiana, November.

http://pubs.naruc.org/pub/4ADC1D5A-2354-D714-5138-F4D19F047EBA.

Bushnell, James B., and Catherine Wolfram. 2005. "Ownership Change, Incentives and Plant Efficiency: The Divestiture of U.S. Electric Generation Plants."

http://faculty.haas.berkeley.edu/wolfram/papers/Divest_0331.pdf.

CAISO (California Independent System Operator). 2009. "Market Optimization Details." Technical Bulletin 2009-06-05. Revised November 19. Folsom: California Independent System Operator. www.caiso.com/Documents/TechnicalBulletin-MarketOptimizationDetails.pdf.

—. 2016a. "EIM FAQ." Folsom: California Independent System Operator. https://www.caiso.com/Documents/EIMFAQ.pdf.

_.2016b. "Company Profiles." California Independent System Operator. https://www.caiso.com/Documents/EIMCompanyProfiles.pdf.

Caplan, Elise, and Patrick E. McCullar. 2013. "Markets in Name Only: Mandatory Capacity Markets and Their Adverse Impact on Load-Serving Entities." The Electricity Journal 26(6): 5260. doi:10.1016/j.tej.2013.05.017.

Cicchetti, Charles J., Jeffrey Dubin, and Colin M. Long. 2004. The California Electricity Crisis: What, Why, and What's Next. Boston: Kluwer Academic Publishers.

Craan, Gina. 2009. "MT-209, Locational Based Marginal Pricing.” Presentation.

http://www.nyiso.com/public/markets_operations/services/market training/course_details/index. jsp? course id $=30$.

DOE (U.S. Department of Energy). 2006. Benefits of Demand Response in Electricity Markets and Recommendations for Achieving Them: A Report to the United States Congress Pursuant to Section 1252 of the Energy Policy Act of 2005. Washington, D.C.: U.S. Department of Energy. http://energy.gov/sites/prod/files/oeprod/DocumentsandMedia/DOE_Benefits_of_Demand_Resp onse in_Electricity_Markets_and_Recommendations_for_Achieving Them_Report to_Congres s.pdf.

- 2007. Economic Dispatch of Electric Generation Capacity: A Report to Congress and the States Pursuant to Sections 1234 and 1832 of the Energy Policy Act of 2005. Washington, 
D.C.: U.S. Department of Energy.

http://www.energy.gov/sites/prod/files/oeprod/DocumentsandMedia/final ED 030107 07 rev2.p

df.

2011. The Role of Electricity Markets and Market Design in Integrating Solar

Generation. Solar Integration Series, 2 of 3. Washington, D.C.: U.S. Department of Energy. http://www.eere.energy.gov/solar/pdfs/50058.pdf.

Dyson, Mark, and Ian Kelly. 2016. "Demand Response Wins: U.S. Supreme Court Upholds FERC Order 745." RMI Outlet Blog, January 29.

http://blog.rmi.org/blog_2016_01_29_demand_response_wins_us_supreme_court upholds_ferc order 745 .

Ea Energy Analyses and Hagman Energy. 2012. The Nordic Electricity Market and How It Can Be Improved. Copenhagen: Ea Energy Analyses and Hagman Energy. http://www.eaenergianalyse.dk/reports/1174 the _nordic_market_and_potential_improvements.pdf.

EEI (Edison Electric Institute). 2013. State Generation \& Transmission Siting Directory: Agencies, Contacts, and Regulations. Washington, D.C.: Edison Electric Institute. http://www.eei.org/issuesandpolicy/transmission/Documents/State Generation Transmission_Si ting Directory.pdf.

Edison Electric Institute. 2016. “Transmission.” Accessed May 31.

http://www.eei.org/issuesandpolicy/transmission/Pages/default.aspx.

EIA (U.S. Energy Information Administration). 2012. "Electric Generator Dispatch Depends on System Demand and the Relative Cost of Operation." Today in Energy, August 17. http://www.eia.gov/todayinenergy/detail.cfm?id=7590.

_. 2013a. "Federal Power Marketing Administrations Operate across Much of the United States." Today in Energy, June 12. http://www.eia.gov/todayinenergy/detail.cfm?id=11651.

- 2013b. Annual Energy Outlook 2013 with Projections to 2040. DOE/EIA-0383(2013). Washington, D.C.: U.S. Energy Information Administration. http://www.osti.gov/scitech/biblio/1081575.

—. 2015. "Natural Gas Prices." Accessed September 15. https://www.eia.gov/dnav/ng/ng_pri_sum_dcu_nus_a.htm.

—. 2016. "Glossary: Electricity." Accessed September 16. http://www.eia.gov/tools/glossary/?id=electricity.

Ela, E., M. Milligan, A. Bloom, A. Botterud, A. Townsend, and T. Levin. 2014. Evolution of Wholesale Electricity Market Design with Increasing Levels of Renewable Generation. NREL/TP-5D00-61765. Golden, CO: National Renewable Energy Laboratory. http://www.osti.gov/scitech/biblio/1159375. 
Elefant, Carolyn. 2011. Reviving PURPA'S Purpose: The Limits of Existing State Avoided Cost Ratemaking Methodologies in Supporting Alternative Energy Development and A Proposed Path for Reform. Washington, D.C.: Law Offices of Carolyn Elefant. http://www.recycledenergy.com/images/uploads/Reviving-PURPA.pdf.

EPA (U.S. Environmental Protection Agency). 2010. An Overview of PUCs for State Environment and Energy Officials. Washington, D.C.: U.S. Environmental Protection Agency.

ERCOT (Electric Reliability Council of Texas). 2016. "LMP Contour Map: Real-Time Market Locational Marginal Pricing." Last modified October 4.

http://www.ercot.com/content/cdr/contours/rtmLmpHg.html.

Eurelectric. 2012. European Commission Consultation Paper on Generation Adequacy, Capacity Mechanisms, and the Internal Market in Electricity. Brussels: Union of the Electricity Industry. http://www.eurelectric.org/media/73943/eur response to ec conslt_on gen adequacy crm f f inal-2013-301-0001-01-e.pdf.

FERC (Federal Energy Regulatory Commission). 2012. Energy Primer: A Handbook of Energy Market Basics. Washington, D.C.: Federal Energy Regulatory Commission. http://www.ferc.gov/market-oversight/guide/energy-primer.pdf.

- 2014. Assessment of Demand Response \& Advanced Metering, Staff Report. Washington, D.C.: Federal Energy Regulatory Commission. http://www.ferc.gov/legal/staffreports/2013/oct-demand-response.pdf.

—. 2016a. "What FERC Does." Last modified May 24. http://www.ferc.gov/about/fercdoes.asp.

— 2016b. "Glossary." Last modified March 15. http://www.ferc.gov/marketoversight/guide/glossary.asp.

Garg, Rishi. 2015. Electric Transmission Seams: A Primer White Paper. Silver Spring, Maryland: National Regulatory Research Institute. http://pubs.naruc.org/pub/536EF504-2354D714-51F0-1BD9D04A5F7E.

Griffin, James M., and Steven L. Puller. 2005. "Introduction - A Primer on Electricity and the Economics of Deregulation." In Electricity Deregulation: Choices and Challenges, edited by James M. Griffin and Steven L. Puller, 1-30. Chicago: University of Chicago Press. http://econweb.tamu.edu/puller/AcadDocs/primer.pdf.

Griffith, Mark. 2008. “Capacity Markets Demystified.” Fortnightly Magazine, March. https://www.fortnightly.com/fortnightly/2008/03/capacity-markets-demystified.

Hausman, Ezra, Robert Fagan, David White, Kenji Takahashi, and Alice Napoleon. 2006. LMP Electricity Markets: Market Operations, Market Power, and Value for Consumers. Prepared for the American Public Power Association. Cambridge, MA: Synapse Energy Economics. http://www.synapse-energy.com/sites/default/files/SynapseReport.2007-02.APPA .LMPElectricity-Markets.06-060-Report.pdf. 
Hinman, Cynthia. 2014. Introduction to the Energy Imbalance Market. Folsom: California Independent System Operator. http://www.bpa.gov/transmission/CustomerInvolvement/EnergyImbalance-Market/Documents/EIM-Overview-CAISO.pdf.

Hogan, William W. 1993. "A Competitive Electricity Market Model.” Prepared for Harvard Electricity Policy Group. http://www.hks.harvard.edu/fs/whogan/transvis.pdf.

_ 1998. "Competitive Electricity Markets: A Wholesale Primer.” John F. Kennedy School of Government, Harvard University. http://www.hks.harvard.edu/fs/whogan/empr1298.pdf.

Hurley, Doug et al. 2013. Demand Response as a Power System Resource. Montpelier, VT: Regulatory Assistance Project. http://www.raponline.org/document/download/id/6597.

ISO-NE (ISO New England). 2016a. "Industry Standards, Structure, and Relationships." Accessed June 30. http://www.iso-ne.com/about/what-we-do/in-depth/industry-standardsstructure-and-relationships.

—. 2016b. "Financial Transmission Rights." Accessed September 3. http://www.isone.com/markets-operations/markets/financial-transmission-rights.

Jess, Margaret. 1997. "Restructuring Energy Industries: Lessons from Natural Gas.” Energy Information Administration Natural Gas Monthly (May):vii-xxi. http://www.eia.gov/pub/oil_gas/natural_gas/feature_articles/1997/restructuring_energy_industrie s_lessons/pdf/peg.pdf.

Johnson, Christopher W. 2006. "Establishing Public Policy as a Primary Cause of Engineering Failure: Did Market Deregulation Lead to the North American 'Blackout', August 14th 2003?" University of Glasgow.

http://www.dcs.gla.ac.uk/ johnson/papers/Public_Policy/johnson_blackout.pdf.

Joskow, Paul L. 1997. "Restructuring, Competition and Regulatory Reform in the U.S. Electricity Sector." Journal of Economic Perspectives 11(3):119-38. doi:10.1257/jep.11.3.119.

Juris, Andrej. 1998. Development of Competitive Natural Gas Markets in the United States. Washington, D.C.: World Bank. http://siteresources.worldbank.org/EXTFINANCIALSECTOR/Resources/2828841303327122200/141juris.pdf.

Kahn, Edward, Charles A. Goldman, Steven Stoft, and Douglas Berman. 1989. Evaluation Methods in Competitive Bidding for Electric Power. Berkeley, CA: Lawrence Berkeley National Laboratory. http://emp.lbl.gov/publications/evaluation-methods-competitive-bidding-electricpower.

King, J., B. Kirby, M. Milligan, and S. Beuning. 2011. Flexibility Reserve Reductions from an Energy Imbalance Market with High Levels of Wind Energy in the Western Interconnection. NREL/TP-5500-52330. Golden, CO: National Renewable Energy Laboratory. http://www.osti.gov/scitech/biblio/1028530-flexibility-reserve-reductions-from-energyimbalance-market-high-levels-wind-energy-western-interconnection. 
Kirby, Brendan. 2004. Frequency Regulation Basics and Trends. Oak Ridge, TN: Oak Ridge National Laboratory. http://ferc.gov/EventCalendar/Files/20100526085937-

Kirby, \%20Frequency\%20Regulation\%20Basics\%20and\%20Trends.pdf.

Kwoka, John, Michael Pollitt, and Sanem Sergici. 2010. "Divestiture Policy and Operating Efficiency in US Electric Power Distribution.” Journal of Regulatory Economics 38(1):86-109. http://link.springer.com/article/10.1007/s11149-010-9122-3.

Lamoureux, Marcel A. 2001. "FERC's Impact on Electric Utilities." IEEE Power Engineering Review. http://ieeexplore.ieee.org/ie15/39/20513/00948252.pdf?arnumber=948252.

Lelic, Izudin. 2016a. "Locational Marginal Pricing (LMP)." Presented at the Introduction to Wholesale Electricity Markets (WEM 101), ISO New England, Northampton, Massachusetts, April 4-8. https://www.iso-ne.com/static-assets/documents/2016/04/20160404-07-wem101$\underline{\text { lmp.pdf. }}$

2016b. "Unit Commitment \& Dispatch." Presented at the Introduction to Wholesale Electricity Markets (WEM 101), ISO New England, Northampton, Massachusetts, April 4-8. https://www.iso-ne.com/static-assets/documents/2016/04/20160404-06-wem101-unitcommitment-dispatch.pdf.

Lew, D., and G. Brinkman. 2013. The Western Wind and Solar Integration Study Phase 2: Executive Summary. NREL/TP-5500-58798. Golden, CO: National Renewable Energy Laboratory. http://www.nrel.gov/docs/fy13osti/58798.pdf.

Lew, D., G. Brinkman, E. Ibanez, B. M. Hodge, M. Hummon, A. Florita, and M. Heaney. 2013. The Western Wind and Solar Integration Study Phase 2. NREL/TP-5500-55588. Golden, CO: National Renewable Energy Laboratory. http://www.osti.gov/scitech/biblio/1095399.

Maize, Kennedy. 2014. “Texas and the Capacity Market Debate.” POWER Magazine, February 1. http://www.powermag.com/texas-and-the-capacity-market-debate/.

McLellan, Malcolm, and Carol Opatrny. 2011. "Maintaining a Balance: Innovation in Power System Balancing Authorities." Washington Journal of Environmental Law \& Policy. http://www.nippc.org/upload/McLellan\%20CCO\%20WJELP\%20Article\%20081012.pdf.

Merrill, Hyde M. 2000. “The RTO Debate.” IEEE Power Engineering Review. http://ieeexplore.ieee.org/iel5/39/17779/00819912.pdf?arnumber=819912.

MISO (Midcontinent Independent System Operator). 2015. "Seams Coordination." https://www.misoenergy.org/Library/Repository/Communication\%20Material/OnePagers/One\%20Pager\%20-\%20Seams\%20Coordination.pdf.

Monitoring Analytics. 2010. Analysis of the 2013/2014 RPM Base Residual Auction Revised and Updated. Eagleville, PA: Monitoring Analytics

http://www.monitoringanalytics.com/reports/Reports/2010/Analysis_of 2013 2014_RPM Base Residual Auction 20090920.pdf. 
Mossavar-Rahmani, Bijan. 2003. Thinking the Unthinkable. Madrid: Fundación Repsol YPF.

NERC (North American Electric Reliability Corporation). 2009. Accommodating High Levels of Variable Generation. Princeton, NJ: North American Electric Reliability Corporation. http://www.nerc.com/files/ivgtf report 041609.pdf.

_. 2014a. "NERC Compliance Registry List." http://www.nerc .com/pa/comp/Registration\%20and\%20Certification\%20DL/NERC_Compliance_Registry_Matr ix_Summary20140827.pdf.

—. 2016a. "North American Electric Reliability Corporation." Accessed September 12. http://www.nerc.com.

. 2016b. "NERC Reliability Coordinators." Accessed October 4. http://www.nerc.com/pa/rrm/TLR/Pages/Reliability-Coordinators.aspx.

New York Independent System Operator (NYISO). 2016. "ISO/RTO Council." http://www.nyiso.com/public/markets_operations/services/planning/iso_rto/index.jsp.

NREL (National Renewable Energy Laboratory). 2015. "Renewable Energy on the Grid: Redefining What's Possible.” NREL/BR-6A20-63367. Golden, CO: National Renewable Energy Laboratory. http://www.nrel.gov/docs/fy15osti/63367.pdf.

O'Connor, Philip R., and Erin M. O'Connell-Diaz. 2015. Evolution of the Revolution: The Sustained Success of Retail Electricity Competition. Washington, D.C.: COMPETE Coalition. http://competecoalition.com/files/COMPETE\%20White\%20Paper_Evolution\%20of\%20Revoluti on_Final.pdf.

Paulos, Bentham. 2014. "FERC Order 745 and the Epic Battle Between Electricity Supply and Demand." POWER Magazine, December 18. http://www.powermag.com/ferc-order-745-andthe-epic-battle-between-electricity-supply-and-demand/.

Pfeifenberger, Johannes, and Kathleen Spees. 2013. "Characteristics of Successful Capacity Markets." Presented at the APEx Conference 2013, New York, New York, October 31. http://www.brattle.com/system/publications/pdfs/000/004/951/original/Characteristics_of_Succe ssful_Capacity_Markets_Pfeifenberger_Spees_Oct_2013.pdf?1383246105.

PJM. 2016a. Demand Response. Audubon, PA: PJM. http://www.pjm.com/ /media/about$\mathrm{pjm} /$ newsroom/fact-sheets/demand-response-fact-sheet.ashx.

_. 2016b. "FERC Order 1000 Implementation." Accessed May 13.

http://www.pjm.com/planning/rtep-development/expansion-plan-process/ferc-order-1000.aspx.

Posner, Barry. 2015. "The Fundamentals of Electricity Markets." Pennsylvania State University. https://www.e-education.psu.edu/ebf200wd/node/151.

Price, Ken. n.d. "SCED, Security Constrained Economic Dispatch.” Texas Reliability Entity. 
Ran Kim, S., and A. Horn. 1999. Regulation Policies Concerning Natural Monopolies in Developing and Transition Economies. DESA Discussion Paper No. 8. New York: United Nations Division for Public Economics and Public Administration.

http://www.un.org/esa/esa99dp8.pdf.

RAP (Regulatory Assistance Project). 2011. Electricity Regulation in the US: A Guide.

Montpelier, VT: Regulatory Assistance Project. http://www.raponline.org/wpcontent/uploads/2016/05/rap-lazar-electricityregulationintheus-guide-2011-03.pdf.

Richts, Christoph, Phillip Strauß, and Detlev Heinemann. 2015. GIZ-India Green Energy Corridors: Report on Forecasting, Concept of Renewable Energy Management Centres and Grid Balancing. Bonn, Germany: Deutsche Gesellschaft für Internationale Zusammenarbeit (GIZ). http://mnre.gov.in/file-manager/UserFiles/draft-report-fscb-remcs.pdf.

RTO Insider. 2013. "MISO Completes Entergy Integration; Largest RTO by Geography." RTO Insider. December 22. https://www.rtoinsider.com/miso-largest-rto/.

SNL. http://www.snl.com/

Spees, Kathleen, et al. 2013. "Capacity Markets - Lessons Learned from the First Decade." Economics of Energy \& Environmental Policy 2(2). doi:10.5547/2160-5890.2.2.1.

Stark, Greg. 2012. "Why FERC Order 1000 Is a Big Deal in the Electric Industry." Energy Currents: Enerdynamics Blog, November 30. https://blog.enerdynamics.com/2012/11/30/whyferc-order-1000-is-a-big-deal-in-the-electric-industry/.

Turner, David. 2016. "Day-Ahead Energy Markets." Presented at the Introduction to Wholesale Electricity Markets (WEM 101), ISO New England, Northampton, Massachusetts, April 4-8. https://www.iso-ne.com/static-assets/documents/2016/04/20160404-08-wem101-day-aheadenergy-market.pdf.

Walton, Robert. 2015. "Supreme Court Appeal on FERC Order 745 Leaves Demand Response in Limbo." Utility Dive, January 21. http://www.utilitydive.com/news/supreme-court-appeal-onferc-order-745-leaves-demand-response-in-limbo/354596/.

Warwick, W.M. 2002. A Primer on Electric Utilities, Deregulation, and Restructuring of U.S. Electricity Markets. PNNL-13906. Richland, WA: Pacific Northwest National Laboratory.

Wolfram, Catherine. 2003. "The Efficiency of Electricity Generation in the US after Restructuring." Presented at the Electricity Deregulation Conference, Bush Presidential Center, Texas A\&M, April 4. http://faculty.haas.berkeley.edu/wolfram/papers/texasamf.pdf. 


\section{Appendix A. Midcontinent Independent System Operator}

$\begin{array}{ll}\text { Start of operations } & 1998 \\ \text { Total capacity available } & 193 \mathrm{GW} \\ \text { Reserve margin } & 17.2 \% \\ \text { Renewable energy capacity } & 14.5 \mathrm{GW} \\ \text { Day-ahead energy market } & \text { LMP-based } \\ \text { Real-time energy market } & \text { LMP-based } \\ \text { Sub-hourly scheduling } & 15 \text {-minute intervals } \\ \text { Financial transmission rights } & \text { Yes } \\ \text { Capacity market } & \text { Yes } \\ \text { Ancillary service markets } & \text { Regulation and contingency reserves, demand response } \\ \text { Territory served } & \text { All or most of Illinois, Indiana, Iowa, Michigan, } \\ & \text { Minnesota, Nebraska, South Dakota, and Wisconsin; } \\ & \text { parts of Arkansas, Kentucky, Louisiana, Mississippi, } \\ & \text { Missouri, Montana, and Texas. }\end{array}$

Sources: MISO (2016a); MISO (2016b); FERC (2016)

\section{History}

In 1998, with encouragement from FERC, several transmission owners came together to establish the Midcontinent ISO (MISO). After obtaining FERC approval as an RTO in December 2001, MISO began providing reliability coordination and regional planning services, generation interconnection, regional planning, market monitoring, and dispute resolution. In 2013, MISO expanded to areas in Arkansas, Mississippi, Louisiana and Texas, and became the ISO/RTO with the largest territory in North America (RTO Insider 2013).

\section{Markets and Operations}

MISO's Open Access Transmission Tariff ensures unbundled transmission rates and allows MISO to provide regional transmission services. MISO launched a Competitive Regional Energy Market and began administering a Financial Transmission Rights market in 2005. MISO became the region's BA with the launch of the Ancillary Services Market in 2009.

MISO uses LMPs to clear its day-ahead and real-time energy market, known as the Day-2 market, at specific times and locations. LMPs in the real-time market are calculated at fiveminute intervals and hourly for the day-ahead market. Hourly LMPs are aggregated into five regional hub prices. A market for FTR allocation is administered in a monthly auction.

\section{Renewable Energy Integration}

The share of non-hydro renewable generation in MISO's system increased from $1 \%$ in 2005 to $6 \%$ (Figure A-1) in 2015. Most of the growth in non-hydro renewable capacity is from wind energy, which accounted for $6 \%$ of total generation in 2015. 

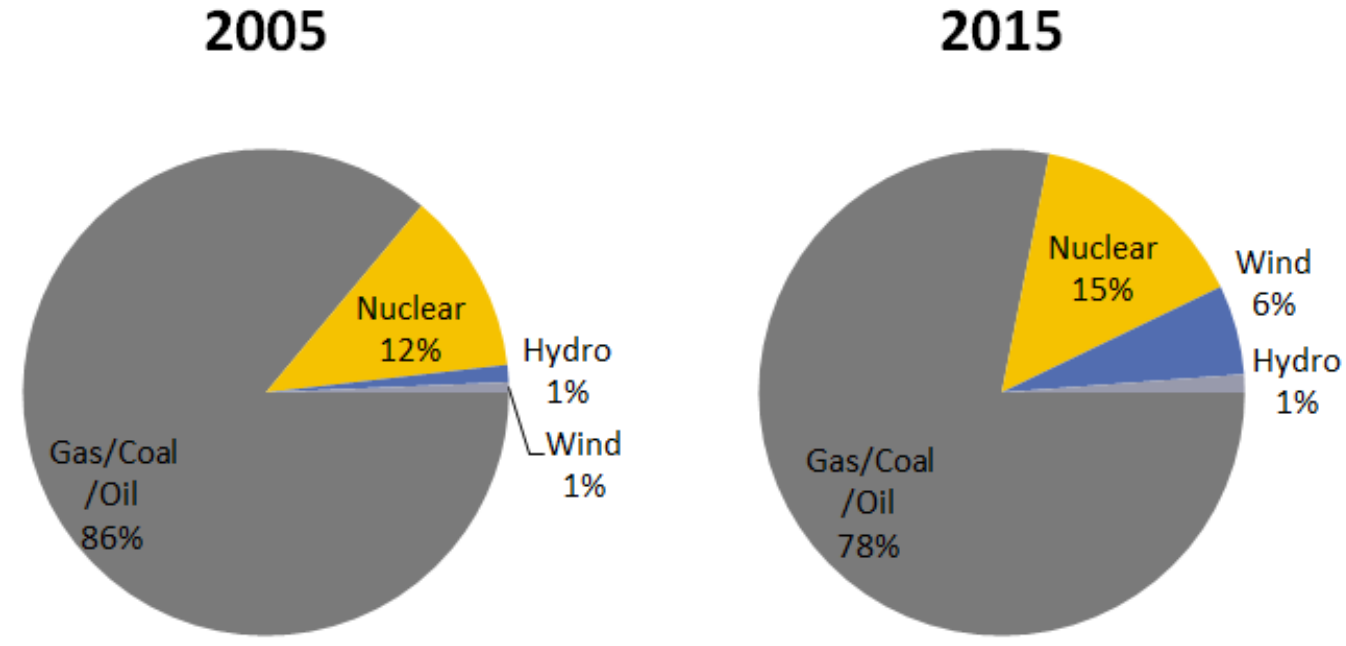

Figure A-1. MISO annual generation by fuel

Source: SNL

Energy Markets Participation. Most VG resources are classified as a Dispatchable Intermittent Resource (DIR) and required to participate in the real-time market. A VG resource classified as an Intermittent Resource (IR) can set the market price if it is designated as a "capacity resource."

Ancillary Services. VG resources are not presently allowed to provide ancillary services.

Forecasting. MISO has a centralized wind power forecasting service that provides hourly forecasts for each hour of the next week. Short-term generation forecasts for the next six hours, are updated every five minutes.

Capacity Market. VG resources are allowed to participate in MISO's capacity market. VG capacity value is determined using unit-specific Effective Load Carrying Capacity performance data.

\section{References}

MISO. n.d. "MISO Operations FAQ."

https://www.misoenergy.org/Library/Repository/Communication\%20Material/About\%20Us_FA Q/OperationsFAQ.pdf.

Porter, Kevin, Kevin Starr, and Andrew Mills. 2015. Variable Generation and Electricity Markets. Reston, VA: Utility Variable Generation Integration Group. http://uvig.org/wpcontent/uploads/2015/05/VGinmarketstableApr2015.pdf.

MISO. 2016a. "Corporate Information."

https://www.misoenergy.org/Library/Repository/Communication\%20Material/Corporate/Corpor ate $\% 20$ Fact $\% 20$ Sheet.pdf.

MISO. 2016b. "Ramp Product Questions and Answers."

https://www.misoenergy.org/Library/Repository/Communication\%20Material/Strategic\%20Initi atives/Ramp\%20Product\%20Questions\%20and\%20Answers.pdf. 
MISO. 2015. Draft Issues Statement on Facilitating Resource Adequacy in the MISO Region. Carmel, IN: MISO.

https://www.misoenergy.org/Library/Repository/Meeting\%20Material/Stakeholder/SAWG/2015 20150305/20150305\%20SAWG\%20Item\%2002\%20Resource $\% 20$ Adequacy $\% 20$ Issues $\% 20$ Stat ement.pdf.

FERC. 2016. "Electric Power Markets: Midcontinent (MISO)." Last modified March 10. http://www.ferc.gov/market-oversight/mkt-electric/midwest.asp. 


\section{Appendix B. PJM Interconnection}

Start of operations

Total capacity available

Reserve margin

Renewable energy capacity

Day-ahead energy market

Real-time energy market

Sub-hourly scheduling

Financial transmission rights

Capacity market

Ancillary service markets

Territory served
1927

$165 \mathrm{GW}$

$25 \%$

$10 \mathrm{GW}$

LMP-based

LMP-based

Yes

Yes

Yes

Regulation, synchronized and supplemental reserves.

All or parts of Delaware, Illinois, Indiana, Kentucky, Maryland, Michigan, New Jersey, North Carolina, Ohio, Pennsylvania, Tennessee, Virginia, West Virginia, and the District of Columbia.

\section{History}

The origins of PJM date to 1927, when three utilities in New Jersey and Pennsylvania formed an interconnection to share their generating resources and operate more efficiently. Since then, more than a dozen utilities and transmission system owners have joined PJM. In 1997, PJM became the first ISO in the United States, and in 2001, the first RTO.

\section{Markets and Operations}

PJM has operated its energy market since 1997. PJM uses LMPs to clear its day-ahead and realtime energy markets at specific times and locations. LMPs in the real-time market are calculated at five-minute intervals and hourly for the day-ahead market.

PJM's capacity market is called the reliability pricing model and was established in 2007. PJM requires LSEs to have enough capacity to meet demand, plus a contingency reserve. LSEs can meet this requirement through their own capacity, bilateral contracts, or through PJM's reliability pricing model. Electricity generation, energy efficiency, and DR are eligible to participate in the capacity market.

\section{Renewable Energy Integration}

The share of non-hydro renewable generation in PJM's system has increased from 1\% in 2005 to $2 \%$ in 2015 (Figure B-1). Non-hydro renewable resource capacity currently represents 5\% of the total capacity available in PJM. 
2005

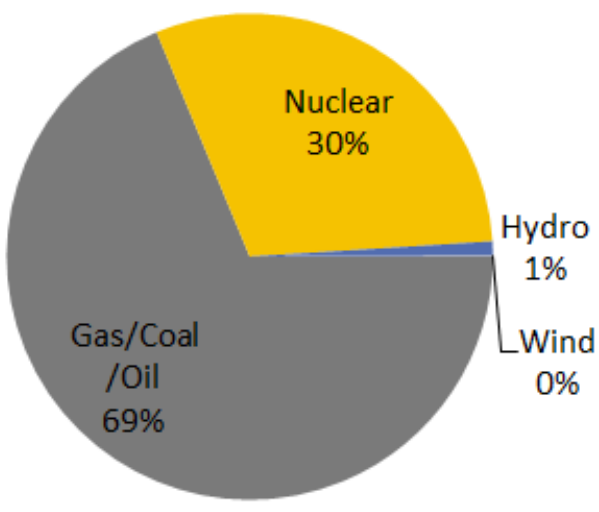

2015

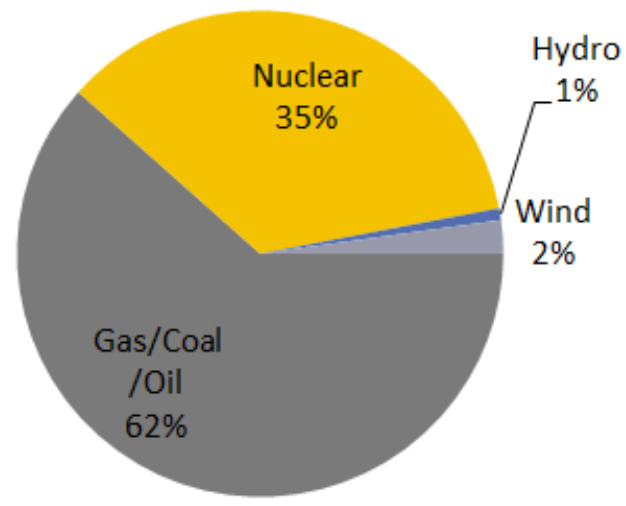

Figure B-1. PJM annual generation by fuel

Source: SNL

Energy Markets Participation. VG resources are allowed to bid into PJM's day-ahead markets and set the market price. Deviations from day-ahead schedules are settled at the real time price.

Ancillary Services. Wind resources that comply with eligibility requirements are allowed to participate in day-ahead and real-time markets for ancillary services, except for regulation. PJM requires PV systems to provide reactive power regulation, limit ramping rates, and limit ride through voltage frequency disturbances.

Forecasting. PJM has a centralized wind power forecasting service used to determine next-day unit commitments and encourage wind resource participation in the day-ahead energy market. The forecasting service is also used to evaluate day-ahead congestion and to allocate resources to respond to wind fluctuations. PJM does not have a forecasting system for PV.

Capacity Market. VG resources are allowed to participate in PJM's capacity market. VG capacity value is determined by the average plant performance over the three previous summers, or $38 \%$ of nameplate capacity for wind and $13 \%$ for PV if performance data are not available.

\section{References}

EIA (U.S. Energy Information Administration). 2014. "NERC's Summer Reliability Assessment Highlights Regional Electricity Capacity Margins.” Today in Energy, June 20.

http://www.eia.gov/todayinenergy/detail.cfm?id=16791.

PJM Interconnection. 2015. "PJM's Support for Variable Resources." http://www.pjm.com/ /media/about-pjm/newsroom/fact-sheets/support-variable-resources.ashx.

PJM Interconnection. 2016. “Territory Served.” Accessed October 12. http://www.pjm.com/about-pjm/who-we-are/territory-served.aspx. 
PJM. 2016. “Today's Outlook.” Accessed September 16. http://www.pjm.com/markets-andoperations.aspx.

PJM. 2015. "New Standards to Connect Renewables to the Grid." Inside Lines. http://insidelines.pjm.com/new-standards-to-connect-renewables-to-the-grid/.

Porter, Kevin, Kevin Starr, and Andrew Mills. 2015. Variable Generation and Electricity Markets. Reston, VA: Utility Variable Generation Integration Group. http://uvig.org/wpcontent/uploads/2015/05/VGinmarketstableApr2015.pdf. 


\section{Appendix C. Public Service Company of Colorado (PSCo) Balancing Authority}

$\begin{array}{ll}\text { Start of operations } & 1924 \\ \text { Total capacity available } & 14 \mathrm{GW} \\ \text { Reserve margin } & 16.3 \% \\ \text { Renewable energy capacity } & 4.4 \mathrm{GW} \\ \text { Day-ahead energy market } & \text { No } \\ \text { Real-time energy market } & \text { No } \\ \text { Sub-hourly scheduling } & \text { Yes } \\ \text { Financial transmission rights } & \text { No } \\ \text { Capacity market } & \text { No } \\ \text { Ancillary service markets } & \text { No } \\ \text { Territory served } & \text { Colorado }\end{array}$

\section{History}

The Public Service Company of Colorado (PSCo) was created in 1924 after a series of mergers and acquisitions among gas and electric utilities servicing Denver and several rural Colorado towns. By 1943, the company served 80\% of Colorado's gas and electric needs. PSCo is currently an operating subsidiary of the utility holding company Xcel Energy Inc., which serves more than 3.3 million electric customers across eight Western and Midwestern states. The American Wind Energy Association (AWEA) ranked Xcel Energy as the top wind energy provider for twelve consecutive years from 2004-2015. By the end of 2015, Xcel had 2,505 MW of wind capacity installed in Colorado. Wind generation contributed to $16 \%$ of the annual load of PSCo's BA in 2015 (Figure C-1). The company projects a 31\% reduction in carbon emissions by 2020 compared to 2005 levels.

\section{Markets and Operations}

PSCo, operating under the name Xcel Energy Colorado, functions as a vertically integrated utility that provides electric service to 1.3 million wholesale and retail customers in Colorado. PSCo is not part of an RTO and does not operate a day-ahead or real-time energy market. The BA's peak load was 6,646 MW in 2013.

Daily system resource planning is handled by determining the capacity, responsiveness, and flexibility of each generator in the system. In 2011, PSCo adopted sub-hourly scheduling under the Wind Reserve Guideline to ensure that enough stand-by generation capacity is available to respond to wind ramp-down events. Since January 2016, PSCo uses 15-minute intervals in its intra-hour scheduling. 


\section{Renewable Energy Integration}

The share of non-hydro renewable generation in PSCo's system has increased from less than $1 \%$ in 2001 to $16 \%$ in 2015 (Figure C-1). Wind power capacity represented 19\% of the total summer capacity available in 2015 (SNL). To accommodate larger penetrations of wind capacity, PSCo has made technological modifications to lower the minimum generation level of combined cycle gas plants and updated gas turbines to improve start-up times.

2005

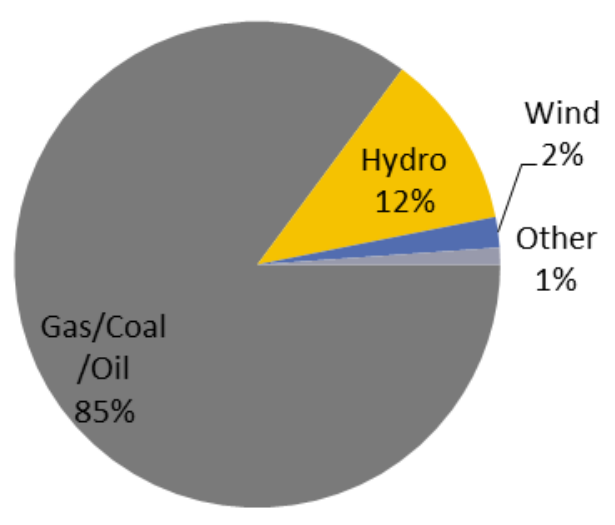

2015

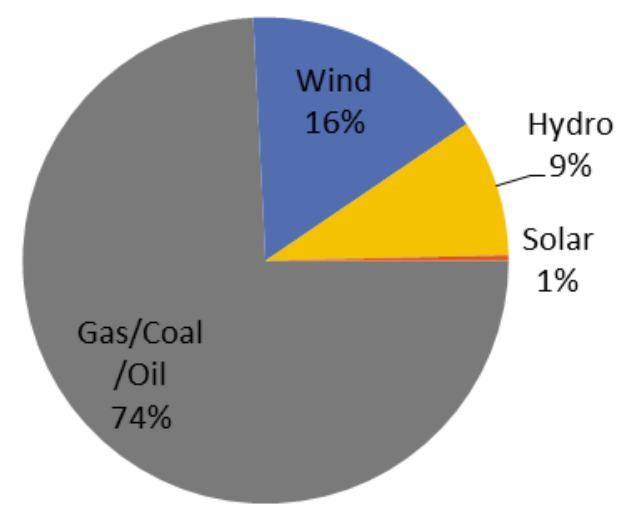

Figure C-1. PSCo annual generation by fuel

Source: SNL

Regulated Monopoly. PSCo operates as a monopoly regulated by the Colorado Public Utilities Commission. Therefore, PSCo does not operate or participate in competitive electricity markets. PSCo, as the sole IOU in Colorado, must comply with the state's $30 \%$ by 2020 renewable energy standard.

Integrated Resource Plans. The PUC requires PSCo to file an integrated resource plan approximately every five years. The plan helps regulators determine the need for additional generation resources. The plan must contain expected load growth for the relevant period and several portfolios that would meet expected demand through different combinations of generation, energy efficiency, and DR resources. The PUC regulators examine the cost and benefits of each portfolio and the methodology that PSCo used to calculate costs, benefits, and technical reliability. The PUC selects the portfolio that best meets demand and other state goals, such as energy efficiency and renewable energy standards, in a reliable and cost-effective manner. The PUC also stipulates the rate of return that it deems sufficient for PSCo to raise equity.

Forecasting. PSCo uses an advanced wind forecasting system that was developed in collaboration with the National Center for Atmospheric Research (NCAR). The forecast is updated every 15 minutes based on inputs from satellites, planes, weather stations, and sensors on wind turbines. 


\section{References}

AWEA (American Wind Energy Association). 2016. AWEA U.S. Wind Industry Annual Market Report Year Ending 2015.

Funding Universe. 2015. "Public Service Company of Colorado History." Accessed September 3. http://www.fundinguniverse.com/company-histories/public-service-company-of-coloradohistory/.

Kirby, Brendan. 2007. "Ancillary Services: Technical and Commercial Insights." http://www.consultkirby.com/files/Ancillary Services -

Technical_And_Commercial_Insights_EXT_pdf.

PSCo (Public Service Company of Colorado). 2011. 2011 Electric Resource Plan, Volume 1. Denver: Public Service Company of Colorado.

Weiss, Jurgen, and Bruce Tsuchida. "Integrating Renewable Energy into the Electricity Grid." 2015. The Brattle Group. https://mseia.net/site/wp-content/uploads/2012/05/AEEI-RenewablesGrid-Integration-Case-Studies.pdf 